\title{
Economic impacts of climatic variability and subsidies on European agriculture and observed adaptation strategies
}

\author{
Pytrik Reidsma • Alfons Oude Lansink • Frank Ewert
}

Received: 30 March 2007 / Accepted: 2 June 2008 /

Published online: 25 June 2008

(C) The Author(s) 2008

\begin{abstract}
In order to assess agricultural adaptation to climate impacts, new methodologies are needed. The translog distance function allows assessing interactions between different factors, and hence the influence of management on climate impacts. The Farm Accountancy Data Network provides extensive data on farm characteristics of farms throughout the EU15 (i.e. the 15 member states of the European Union before the extension in 2004). These data on farm inputs and outputs from 1990-2003 are coupled with climate data. As climate change is not the only change affecting European agriculture, we also include effects of subsidies and other changes on inputs and outputs of farms throughout Europe. We distinguish several regions and empirically assess (1) climate impacts on farm inputs and outputs in different regions and (2) interactions between inputs and other factors that contribute to the adaptation to these impacts. Changes in production can partly be related to climatic variability and change, but also subsidies and other developments (e.g. technology, markets) are important. Results show that impacts differ per region, and that 'actual impacts' cannot be explicitly separated into 'potential impacts' and 'adaptive capacity' as often proposed for vulnerability assessment. Farmers adapt their practices to prevailing conditions and continuously adapt to changing conditions. Therefore, 'potential impacts' will not be observed in practice, leaving it as a mainly theoretical concept. Factors that
\end{abstract}

P. Reidsma $(\bowtie) \cdot$ F. Ewert

Department of Plant Sciences, Group Plant Production Systems, Wageningen University, P.O. Box 430, 6700 AK Wageningen, The Netherlands

e-mail: pytrik.reidsma@wur.nl

P. Reidsma

Netherlands Environmental Assessment Agency (RIVM/MNP), P.O. Box 1, 3720 BA Bilthoven, The Netherlands

A. Oude Lansink

Department of Social Sciences, Business Economics, Wageningen University, P. O. Box 8130, 6700 EW Wageningen, The Netherlands

F. Ewert

Institute of Crop Science and Resource Conservation (INRES), University of Bonn, Katzenburgweg 5, D - 53115 Bonn, Germany 
contribute to the adaptation also differ per region. In some regions more fertilizers or more irrigation can mitigate impacts, while in other regions this amplifies impacts. To project impacts of future climate change on agriculture, current farm management strategies and their influence on current production should be considered. This clearly asks for improved integration of biophysical and economic models.

Keywords Adaptation - Agriculture - Climate change · Economic vulnerability Frontier analysis

\section{Introduction}

European agriculture is facing multiple challenges of global change. Global warming is already apparent and will impact future agriculture (Gitay et al. 2001). In the shorter term, trade liberalization, new demand for land for biofuels and the global food market will affect trade and production (van Meijl et al. 2006). Agricultural policies have long been focused on increasing food production and the viability of rural economies. In recent years, globalization of agricultural markets and environmental issues became major factors influencing the Common Agricultural Policy (CAP) in Europe. Farmers will need to adapt to climate change in the context of globalization and changing policies.

O'Brien and Leichenko (2000) introduced the concept of 'double exposure', proposing to consider the joint impact of both globalization and climate change. Several integrated projects have expanded this concept and consider 'multiple exposures' (e.g. Schröter et al. 2005; Westhoek et al. 2006). The narratives of the Intergovernmental Panel on Climate Change (IPCC) - Special Report on Emission Scenarios (Nakícenovíc et al. 2000), which aimed at projecting $\mathrm{CO}_{2}$ emissions, have not only been used to project climate change and its impacts, but also to develop scenarios that explicitly consider globalization and other drivers influencing global and European food production and land use (Ewert et al. 2005; Rounsevell et al. 2005; Rounsevell et al. 2006). Yet, there is little empirical evidence on how these drivers influence European agriculture.

The vulnerability of European agriculture can be determined by exposure, sensitivity and adaptive capacity (IPCC 2001; Metzger 2005). Exposure and sensitivity determine the potential impact; including the adaptive capacity will result in the residual or actual impact. The potential impact of climate change on agricultural yields is projected to be mainly positive for Northern Europe and mainly negative for Southern Europe (Gitay et al. 2001; Olesen and Bindi 2002; Ewert et al. 2005). However, farmers can and do adapt in order to reduce negative impacts. In this paper we explore when, how and to what extent farmers adapt to different stimuli.

A cross-sectional analysis in the EU15 (i.e. the 15 member states of the European Union before the extension in 2004) showed that next to climate, the farm characteristics input intensity, economic size and the type of land use are important factors influencing spatial variability in crop yields and farmers' income (Reidsma et al. 2007). Temporal analyses indicated that these farm characteristics also have an impact on trends and variability in crop yields and farmers' income (Reidsma 2007; Reidsma and Ewert 2008). Climate impacts do not only vary among regions, but also among farm types. Studies that quantified adaptive capacity based on generic socio-economic indicators (Schröter et al. 2003; Metzger et al. 2006) suggested that the Mediterranean regions had a lower adaptive capacity than temperate and Nordic regions. Reidsma (2007) however showed that the actual impacts of increasing temperatures are not more severe in Mediterranean compared 
to temperate regions, suggesting adaptation of farmers to prevailing conditions. Still, it is not clear how socio-economic conditions and farm management interact with climate to adapt to climate impacts.

An influential method in economic analysis of climate change impacts is the Ricardian approach which was introduced by Mendelsohn et al. (1994). The Ricardian approach however addresses spatial differences in climatic conditions, not temporal change. Also, adaptation is implicitly included in the impacts, but not explicitly addressed. An approach often used in econometric studies, but not yet applied in studies related to climate impacts, is frontier analysis (Farrell 1957; Morrison Paul et al. 2000). Frontier estimation models provide a useful methodology to analyse determinants of technical efficiency and explore the contributions of inputs and other factors (e.g. climate, subsidies and management) on deviations from efficient production. Including multiple inputs and outputs in a translog distance function allows assessing interactions between e.g. climate and management (adaptation strategies).

In this study we assess the impact of climate variability and subsidies on inputs and outputs of farms in several European regions in the context of other changes. We use a translog distance function representing multiple outputs, inputs, and external factors to analyse (1) the actual impact of climate variability and subsidies on multiple outputs (actual impact), (2) which inputs can decrease impacts of climate variability and subsidies (factors influencing adaptation), and (3) the impact of climate variability and subsidies on inputs (adaptation strategies). The focus is on arable farming, but other farm types are also included in the model.

\section{Methodology}

\subsection{The translog distance function}

The translog distance function is a special form of a frontier estimation model. Frontier econometric techniques allow noise from measurement error to be separated from the technical efficiency arising from farms not reaching the boundary or the 'best practice'

Fig. 1 The production frontier. The production frontier determines the maximum output $\mathrm{Y}$ that can be achieved from a set of inputs $\mathrm{X}$ given the levels of external factors $\mathrm{R}$. If in situation 1 a farm is operating at a point $A$, the farm is on the best practice frontier with an efficiency ratio of 1. If a farm is at point $B$ then the farm is technically inefficient. In another region or at a later stage the frontier may shift to situation 2, for which $C$ denotes an efficient farm and $D$ denotes an inefficient farm

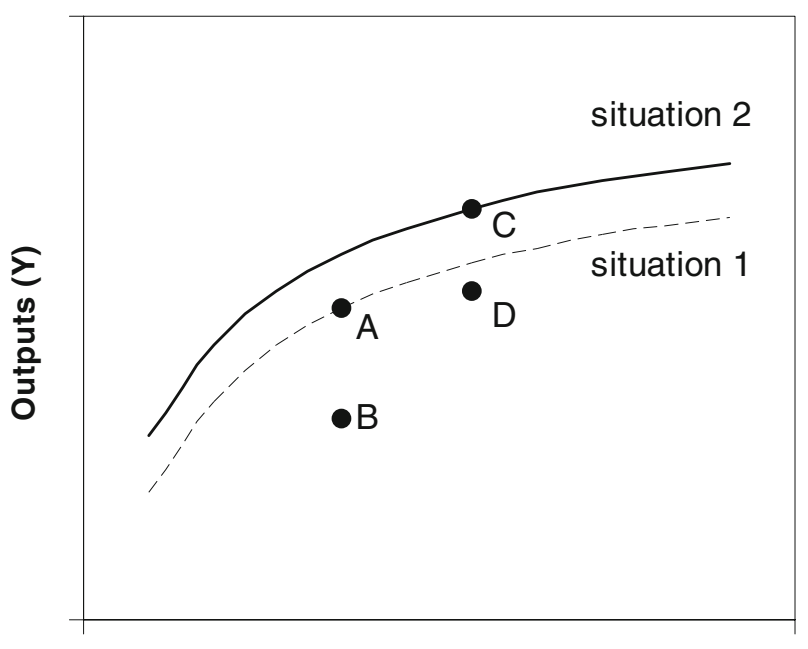

Inputs (X) 
technology, through a two-part error term in the estimation process. In a frontier estimation model the technical efficiency of an individual farm is measured via its deviation from the frontier (Fig. 1). Typically, the model includes one output and multiple inputs. In order to represent interactions between multiple outputs and inputs, the distance function is developed (Färe 1988; Färe et al. 1994; Morrison Paul et al. 2000; Morrison Paul and Nehring 2005), which is represented by

$$
D_{o}(X, Y, R)=\min \{\Theta ; Y / \Theta\} \in P(X, R)
$$

$P(X, R)$ is the set of output vectors $Y$ that can be produced using the input vector $X$, given the levels of external factors $R$. The distance function $D_{o}(X, Y, R)$ defines the maximum output $Y$ possible to produce given input $X$, defined according to $P(X, R)$. The distance function then represents the distance from the frontier; if $Y$ is on the production set boundary, the distance function is equal to 1 . A value below 1 indicates a deviation of the farm from 'best-practice' production, technical efficiency.

A flexible form of the distance function is the translog functional form (Coelli and Perelman 2000; Morrison Paul et al. 2000), because it incorporates all second-order (interaction) terms across outputs and inputs. It allows representation of substitution possibilities without restrictive assumptions about the shape of the technological relationship. The translog distance function takes the form

$$
\begin{aligned}
\ln D_{\mathrm{o} i}= & 0+\sum_{m} m \ln y_{m i}+\sum_{k} k_{k} \ln x_{k i}+\sum_{f} \ln r_{f i} \\
& +0.5 \sum_{m} \sum_{n}{ }_{m n} \ln y_{m i} \ln y_{n i}+0.5 \sum_{k} \sum_{l}{ }_{k l} \ln x_{k i} \ln x_{l i}+0.5 \sum_{f} \sum_{g} f g \ln r_{f i} \ln r_{g i} \\
& +\sum_{m} \sum_{k}^{m} m \ln y_{m i} \ln x_{k i}+\sum_{m} \sum_{f} m f \ln y_{m i} \ln r_{f i}+\sum_{k} \sum_{f} k f \ln x_{k i} \ln r_{f i}
\end{aligned}
$$

In this function, $o$ indicates an output-orientated distance function and $i$ denotes the farm. The summation sign over $m, n$ implies summation over $M$ outputs, $k, l$ over $K$ inputs and $f, g$ over $F$ external factors, with $\alpha, \beta$, and $\gamma$ parameters to be estimated. Restrictions required for homogeneity and symmetry (Coelli and Perelman 2000; Morrison Paul et al. 2000) can be imposed by normalizing over one of the outputs $y_{1}$. In the normalized function $\ln D_{o i} / y_{1 i}$, the distance or technical inefficiency measure $\ln D_{o i}$ can be rewritten as $u_{i}$. Adding the random error term $v_{i}$ then leads to the translog function redefined in terms of $\ln y_{1 i}$ as

$$
\begin{aligned}
\ln y_{1 i} & =0+\sum_{m} \ln y_{m i}^{*}+\sum_{k} k \ln x_{k i}+\sum_{f} \ln r_{f i} \\
& +0.5 \sum_{m} \sum_{n} m n \ln y_{m i}^{*} \ln y_{n i}^{*}+0.5 \sum_{k} \sum_{l}{ }_{k l} \ln x_{k i} \ln x_{l i}+0.5 \sum_{f} \sum_{g} f g \ln r_{f i} \ln r_{g i} \\
& +\sum_{m} \sum_{k} m k \ln y_{m i}^{*} \ln x_{k i}+\sum_{m} \sum_{f}{ }_{m f} \ln y_{m i}^{*} \ln r_{f i}+\sum_{k} \sum_{f} k f \ln x_{k i} \ln r_{f i}+v_{i}-u_{i}
\end{aligned}
$$

where $y_{m}^{*}=1$ is $y_{m} / y_{1}$. The summation sign over $m$ now implies summation over $M-1$ outputs as $y_{1}^{*}=1$. The random error term $v_{i}$ is assumed to be $N\left(,{ }_{V}^{2}\right)$, and independent of the $u_{i}$, which accounts for technical inefficiency in production and is assumed to be independently distributed as truncations at zero of the $N(, \underset{U}{2})$ distribution, where $\eta$ is a parameter to be estimated. The function is slightly adapted by transforming the left side of the equation to be $\ln y_{1}$ rather than $-\ln y_{1}$. This reverses the signs of the parameter 
estimates resulting from a usual distance function, which facilitates comparing estimates with standard production function models (Coelli and Perelman 1996; Morrison Paul et al. 2000). The technical efficiency (TE) is computed as $\exp \left(-u_{i}\right)$.

\subsection{Data description and model specification}

Farm data are obtained from the Farm Accountancy Data Network (FADN; source: FADNCCE-DG Agri and LEI; http://ec.europa.eu/agriculture/rica/index_en.cfm) from 1990-2003. The FADN provides extensive data on farm characteristics of individual farms throughout the EU15 (i.e. the 15 member states of the European Union before the extension in 2004). Data have been collected annually since 1989; for East Germany, Finland and Sweden since 1995. They have been used to evaluate the income of farmers and the consequences of the European CAP. In total, 100 HARM regions are distinguished with more than 50,000 sample farms. HARM is the abbreviation for the harmonized division created by the Dutch Agricultural Economics Research Institute (LEI). It gives the opportunity to compare the different regional divisions of the EU15 used by Eurostat (NUTS; Nomenclature of Territorial Units for Statistics) and FADN. To enable temporal analyses, a farm typology is developed based on the farm characteristics land use, farm size and intensity (Andersen et al. 2006, 2007; Reidsma 2007). We distinguish 21 land use types, three size types and three intensity types. Instead of individual farms, the farm types are used as $i$ in the model specification.

Monthly temperature and precipitation data from 1990-2003 are obtained from the Monitoring Agriculture through Remote Sensing techniques (MARS) project (http://www. marsop.info). MARS data are available per grid cell of $50 \times 50 \mathrm{~km}$ and are averaged per HARM region. The average temperature of the period from January to June $\left(r_{\text {tmean }}\right)$, which covers the main growing period of different crops in different regions in Europe, was computed from the MARS data to obtain the mean temperature for the main growing period

Table 1 Data description of variables included in the translog distance function

\begin{tabular}{ll}
\hline Variable & Description \\
\hline$y_{\text {cer }}=y_{1}$ & Output of cereals, excluding grain maize $(€)^{\mathrm{a}}$ \\
$y_{\text {mai }}$ & Output of grain maize $(€)^{\mathrm{a}}$ \\
$y_{\text {othar }}$ & Output of other arable crops $(€)^{\mathrm{a}}$ \\
$y_{\text {othact }}$ & Output of other agricultural activities $(€)^{\mathrm{a}}$ \\
$x_{\text {fert }}$ & Input of fertilizers and soil improvers $(€)^{\mathrm{a}}$ \\
$x_{\text {prot }}$ & Input of crop protection products $(€)^{\mathrm{a}}$ \\
$x_{\text {size }}$ & Economic size $(\text { ESU; one ESU corresponds to a standard gross margin of } € 1,200)^{\mathrm{a}}$ \\
$x_{\text {irr }}$ & Irrigated area $(\text { ha })^{\mathrm{a}}$ \\
$x_{\text {cer }}$ & Cereal area \\
$x_{\text {mai }}$ & Grain maize area \\
$x_{\text {othar }}$ & Area with other arable crops \\
$x_{\text {othact }}$ & Area with other agricultural activities \\
$r_{\text {tmean }}$ & Mean temperature $\left({ }^{\circ} \mathrm{C}\right)$ of first half year \\
$r_{\text {pmean }}$ & Mean precipitation $(\mathrm{mm})$ of first half year \\
$r_{\text {subs }}$ & Total subsidies $(€)^{\mathrm{a}}$ \\
$r_{\text {year }}$ & Time trend $(1990=1,1991=2, \ldots, 2003=14)^{\mathrm{a}}$ \\
\hline
\end{tabular}

Variables are measured for each year from 1990-2003.

${ }^{a}$ Source: FADN. Scale: farm type

${ }^{\mathrm{b}}$ Source: MARS. Scale: HARM region 
per year. Monthly precipitation data are averaged for the same period (January-June) to obtain the mean precipitation ( $\left.r_{\text {pmean }}\right)$ for the main growing period.

Outputs have been grouped into four groups (Table 1): production of cereals $\left(y_{\text {cer; }}\right.$; excluding grain maize), production of grain maize ( $y_{\text {mai }}$; separated for its spatial relation as it is an important crop in Southern Europe and responds differently to climatic conditions than other cereals), production of other arable crops $\left(y_{\text {othar }}\right)$ and production of other agricultural activities ( $y_{\text {othact }}$; e.g. livestock, permanent cropping). We are mainly interested in arable farming, as arable farming is assumed to be mostly affected by climate change and variability. We include other agricultural activities, as (1) inputs are also used for these activities and (2) the model results can give more information on differences in impacts.

Inputs included in the model are based on general input-output relations. Fertilizer and soil improvers $\left(x_{\text {fert }}\right)$ and crop protection products $\left(x_{\text {prot }}\right)$ are materials used to increase outputs. Economic size $\left(x_{\text {size }}\right)$ is determined on the basis of the overall standard gross margin of the holding. It represents physical capital and labour, as labour is highly correlated to $x_{\text {size }}$ (Reidsma et al. 2007). We include irrigated area $\left(x_{\text {irr }}\right)$ as it influences production and can influence climate impacts (e.g. Darwin 1999; Schlenker et al. 2005). As we are interested in the interaction between climate and land use, we separate land uses into cereal area $\left(x_{\mathrm{cer}}\right)$, grain maize area $\left(x_{\mathrm{mai}}\right)$, other arable crop area $\left(x_{\mathrm{othar}}\right)$ and area with other agricultural activities $\left(x_{\text {othact }}\right)$.

Climatic conditions are external factors that influence production. The mean temperature $\left(r_{\text {tmean }}\right)$ and precipitation $\left(r_{\text {pmean }}\right)$ of the main growing season per year per HARM region are related to the farm types. Subsidies are the main instrument of the CAP; we include total subsidies $\left(r_{\text {subs }}\right)$ as an external factor in the model specification. Next to climate and subsidy changes, also other changes take place. Technological development, markets and other changes are captured in a time trend $\left(r_{\text {year }}\right)$.

As impacts of temporal variability differ per region (Reidsma 2007; Reidsma and Ewert 2008), we apply the model separately for different regions. Within a selected region climatic and socio-economic conditions should be similar, but the number of farm types needs to be larger than the number of variables (including interaction variables) to ensure some degrees of freedom. Eight regions have been distinguished with different average $r_{\text {tmean }}$, decreasing in the order of Greece, Spain, Italy, France, Germany, Benelux (Belgium, The Netherlands and Luxembourg), UK and Scandinavia (Scandin.: Finland, Sweden and Denmark). Most of these regions comprise one country, but several HARM regions. As climatic and socio-economic conditions can differ within regions, results also represent some spatial variability in farm performance.

Farm data that are represented in euros $\left(y_{\mathrm{m}}, x_{\mathrm{fert}}, x_{\mathrm{prot}}\right)$ are corrected for price effects using price indices. Eurostat (http://epp.eurostat.ec.europa.eu) provides price indices from 1995-2003, and absolute prices from 1990-2003. For years or countries where data are missing, price indices can be calculated based on the relationship between absolute prices and price indices from other years or other countries. Only for $x_{\text {prot }}$ no comparable price data for 1990-1994 are available and 1995 data are used. We are confident that this doesn't influence results, as analyses without corrections for price effects showed that input prices have a very small impact. Zeros in the data are represented by a 0.0001 value, to enable calculation of $\ln$ values. As negative values can't be log-transformed, all $r_{\text {tmean }}$ data are first transformed by adding $5^{\circ} \mathrm{C}$, so all $r_{\text {tmean }}>0$. This transformation doesn't affect results as these refer to relative impacts.

We use the LIMDEP (limited dependent variable models) econometric software version 7.0, April 2002, written by William H. Greene (Greene 1995) to estimate our model. Eq. 3 is estimated for eight regions with data from 1990-2003 per farm type. All parameters are 
logged, except for $r_{\text {year }}$. As we are interested in inter-annual variability, we do not use the random effects model, as this model will give a constant $u_{i}$ per farm type over time. The estimated cross-section model will capture both temporal and spatial variability in production.

\subsection{Analysing impacts and adaptation}

\subsubsection{Impact of external factors on overall output}

We can use the distance function to construct farm performance measures (Morrison Paul et al. 2000; Morrison Paul and Nehring 2005) that can give us more information on impacts of climate variability and subsidies on agricultural production. These measures can also indicate which factors contribute to adaptation (reducing impacts) and which factors are adapted to reduce impacts ('adaptation strategies').

The impact of external factors $r_{\mathrm{f}}$ on production of (or contribution to) $y_{1}$ is measured by the elasticity

$$
\varepsilon_{y 1, f}=\partial \ln y_{1} / \partial \ln r_{f}={ }_{f}+\sum_{g} f g \ln r_{g i}+\sum_{k} f k \ln x_{k i}+\sum_{m} f m \ln y_{m i}^{*}
$$

The elasticity represents the percentage change in output following a $1 \%$ change in $r_{\mathrm{f}}$. The change in $y_{1}$ represents change in overall production, since all other factors of the function (and hence the $y_{m} / y_{1}$ ratios) are fixed. The elasticity varies by observation, but is generally estimated at the mean.

The separate components of this elasticity measure represent the interaction effects. For example, the interaction between inputs and external factors $C_{f k}=\gamma_{f k} \ln x_{k}$. The interaction effects can increase or decrease the total impact of $r_{f}$ on production. The $C_{f k}$ components therefore represent indicators of adaptation to variability or change in temperature, precipitation and subsidies. When $\varepsilon_{y 1, r \text { pmean }}$ is positive and $C_{r \text { pmean, } x \text { irr }}$ is negative, this implies that negative impacts of decreasing precipitation can be reduced by increasing the irrigated area.

\subsubsection{Impact of external factors and inputs on output composition}

The impact of external factors $r_{f}$ is not the same on all outputs $y_{m}$. The contribution of output $y_{m}$ to total output can be measured by the elasticity $\varepsilon_{y 1, m}$, which is calculated in a similar way as $\varepsilon_{y 1, f}$ (Eq. 4):

$$
\varepsilon_{y 1, m}=\partial \ln y_{1} / \partial \ln y_{m}={ }_{m}+\sum_{n}{ }_{m n} \ln m_{n i} *+\sum_{k}{ }_{k m} \ln x_{k i}+\sum_{f} f m \ln r_{f i}
$$

The elasticity $\varepsilon_{y 1, m}$ reflects the percentage change in output $y_{1}$ following a $1 \%$ change in output $y_{m}$. Elasticity $\varepsilon_{y 1, m}=\varepsilon_{D o, m}$ for all outputs except $y_{1}$. Due to homogeneity restrictions, the $y_{1}$ elasticity is computed as $\varepsilon_{D o, 1}=-\left(1+\Sigma_{m} \varepsilon_{D o, m}\right)$. For outputs, larger negative terms with respect to $y_{m}$ imply a greater contribution of output $y_{m}$ on total output relative to $y_{1}$ $\left(y_{\text {cer }}\right)$. The sign of $\varepsilon_{y 1, m}$ should be negative, consistent with the slope of the production possibility frontier, as $-\ln y_{1}$ is adapted to $\ln y_{1}$. The interaction terms with respect to the $y_{m}$ variables can be interpreted as the effect of these variables on the contribution of $y_{m}$ to total output relative to $y_{1}$. Hence, the impact of external factors on $y_{m}$ is measured by $C_{m f}=\gamma_{f m} \ln$ $r_{\mathrm{f}}$ (note that for $r_{\text {year }}$ in this term it is not $\ln r_{\text {year }}$, but $r_{\text {year }}$ ). A negative $C_{m f}$ makes $\varepsilon_{y 1, m}$ more 
negative and thus increases the value or contribution of output $y_{m}$ relative to $y_{1}$ (the bias is 'output $y_{m}$-using').

From Eq. 4 we calculated $C_{\mathrm{fk}}$, factors that are interpreted as indicators of adaptation. The $x_{k}$ factors can change the impact of external factors $r_{f}$ on overall output. Clearly, these input factors $x_{k}$ also have their own effect on outputs. The components $C_{m k}=\beta_{k m} \ln x_{k}$ from Eq. 5 provide relative measures of the productive impact of $x_{k}$ on output composition. Different measures can be compared. For example, if $x_{k}$ can change the impact of $r_{\text {tmean }}$ variability on total output (in Eq. 4), in Eq. 5 we can observe which outputs $y_{m}$ are mostly impacted by $x_{k}$.

\subsubsection{Influence of inputs on outputs and adaptation strategies}

The components $C_{m k}$ from Eq. 5 provide information on the impact of input factors $x_{k}$ on specific outputs $y_{m}$. The impact of input $x_{k}$ on total output is measured by the elasticity:

$$
\varepsilon_{y 1, k}=\partial \ln y_{1} / \partial \ln x_{k}={ }_{k}+\sum_{l} k l \ln x_{l i}+\sum_{m}{ }_{k m} \ln y_{m i}^{*}+\sum_{f} f k \ln r_{f i}
$$

We can assess the relative impact of intensity measures $x_{\text {fert }}, x_{\text {prot, }}, x_{\text {irr }}$, economic size $x_{\text {size }}$ and land uses $x_{\text {cer }}, x_{\text {mai }}, x_{\text {othar }}$ and $x_{\text {othact }}$ on production. As the absolute derivate $\partial y_{1} / \partial x_{k}=\partial \ln y_{1} / \partial \ln x_{k} \cdot\left(y_{1} / x_{k}\right)$ corresponds to the marginal product for inputs $M P_{k}$, $\varepsilon_{y 1, k}$ represent the 'output share' of $x_{k}\left(\varepsilon_{y 1, k}=M P_{k} x_{k} y_{1}\right)$. The sum of the output shares represents a scale economy measure, where $\Sigma \varepsilon_{y 1, k}>1$ implies increasing returns to scale; more inputs generate a more than proportionate increase in output (Morrison Paul and Nehring 2005).

Also in Eq. 6 the interaction terms are of special interest. $C_{k f}=\gamma_{f k} \ln r_{f}$ represents the effect of climate, subsidies or time $\left(r_{f}\right)$ on input composition. For example, a positive $C_{x \text { size, }}$ rtmean would imply an increase in $\varepsilon_{y 1, x \text { size }}$ and thus increasing output share from farm size $x_{\text {size }}$ at higher temperatures $r_{\text {tmean. }}$. At higher $r_{\text {tmean }}$ the $x_{\text {size }}$ is thus larger, which can also be interpreted as farms with large $x_{\text {size }}$ being better adapted to higher temperatures. If farms are allocatively efficient and aim to maximize outputs, they increase $x_{\text {size }}$ at higher $r_{\text {tmean }}$.

Our farm typology is based on farm intensity, size and land use. Significant $\gamma_{f k}$ estimates can indicate external factors that determine the presence of different farm types. If $x_{k}$ share (e.g., economic size, input of fertilizers) changes due to $r_{\text {tmean }}$, this can be considered as an adaptation strategy (it may however just as well be maladaptation). By this means we can also assess the impact of climate, subsidies and time on land use. A change of crop choice is considered to be an adaptation strategy (e.g. Smit and Skinner 2002), and is often implicitly included in climate impact models (e.g. IMAGE team 2001; Eickhout et al. 2007). Although only four land uses are distinguished, the $C_{k f}$ measures can give some empirical evidence on crop choice changes in relation to climate change.

\section{Results}

\subsection{Farm performance}

In all regions the explained variance in outputs is very high, $R^{2} \mathrm{~s}$ are close to 1 . Many parameter estimates, including interaction terms, are significant. Effects of inputs and external factors are different in different regions however. The TE is high in all regions and ranges from Italy $(\mathrm{TE}=0.85, \mathrm{SD}=0.07)$, Spain $(\mathrm{TE}=0.86, \mathrm{SD}=0.07), \mathrm{UK}(\mathrm{TE}=0.87, \mathrm{SD}=$ 
$0.09)$, Scandinavia $(\mathrm{TE}=0.88 ; \mathrm{SD}=0.09)$, Greece $(\mathrm{TE}=0.88 ; \mathrm{SD}=0.07)$, France $(\mathrm{TE}=0.90$, $\mathrm{SD}=0.04)$, Germany $(\mathrm{TE}=0.90, \mathrm{SD}=0.06)$ to the Benelux $(\mathrm{TE}=0.94, \mathrm{SD}=0.03)$. This suggests that farms are managed most efficiently in North-West Europe. In regions with lower average technical efficiency there are more farms further away from the frontier, the 'best practice' in the region. But it also indicates there is room for improvement. Significant differences between different farm types and years are observed, but as variables related to farm types and time are included as explaining variables (the frontier for technical efficiency is related to these variables), these will be reflected in the constructed measures.

\subsection{Impacts and adaptation to changes in climate and subsidies}

\subsubsection{Climate impacts on production}

The elasticity measures of the external factors $\varepsilon_{y 1, f}$ (Table 2) indicate that the effects of temperature $r_{\text {tmean }}$ and precipitation $r_{\text {pmean }}$ are fairly strong in relation to subsidies $r_{\text {subs }}$ and time $r_{\text {year }}$ (Table 3). The effects are different per region however. In Greece a $1 \%$ increase in $r_{\text {tmean }}$ would at the mean result in a $0.48 \%$ increase in total production. A large irrigated area $x_{\text {irr }}$ increases this positive effect significantly $\left(C_{\text {rtmean, } x \text { irr }}\right)$. More irrigation can thus be considered as an adaptation to higher temperatures in Greece. In most other regions the effect of $x_{\text {irr }}$ is small, while in Italy a larger $x_{\text {irr }}$ enlarges the negative effect of $r_{\text {tmean }}$. This may be related to irrigated agriculture growing more water demanding crops (while higher $r_{\text {tmean }}$ increases evapotranspiration and thus reduces water availability).

Also in Scandinavia the effect of $r_{\text {tmean }}$ is positive; in other regions and especially France the effect is negative (Fig. 2). Factors that reduce or increase impacts of $r_{\text {tmean }}$ differ per region. For example, in Scandinavia and Greece a higher fertilizer use $x_{\text {fert }}$ reduces positive impacts; in France, Italy and the UK $x_{\text {fert }}$ significantly reduces negative impacts, while in Spain $x_{\text {fert }}$ amplifies negative impacts. These results may be due to activities related to fertilizer use and suggest that in Scandinavia, Greece and Spain and agricultural activities relying on a high fertilizer use are less profitable when temperatures increase, while the opposite is the case in other regions.

Other factors that significantly change impacts of $r_{\text {tmean }}$ on production, are among others economic size $x_{\text {size }}$ in France (smaller farms adapt better) and Spain (larger farms adapt better); cereal area $x_{\text {cer }}$ in Italy (negative) and France (positive); and maize output $y_{\text {mai }}$ and maize area $x_{\text {mai }}$ (negative) in France. Maize thus seems more vulnerable to higher temperatures than other cereals in France, but this is not necessarily the case in other regions. In Italy (and France and Benelux) a higher $r_{\text {pmean }}$ compensates for a high $r_{\text {tmean }}$, but the opposite is the case for the UK. Lastly, the only region where $C_{r \text { tmean, } r \text { year }}$ is (almost) significant, is the UK. This positive interaction term suggests that adaptation to higher temperatures improves over the years in the UK, but not in other regions.

Next to changes in temperature, also changes in precipitation have some impact. The effect of $r_{\text {pmean }}$ is positive in most regions, but slightly negative in the Benelux, UK and Scandinavia (Fig. 3). The negative effect is also increasing in time (negative $C_{r \text { pmean,ryear }}$ ) in these last regions (including Italy). Only in Greece $x_{\text {irr }}$ substantially changes the $\varepsilon_{y 1, r \text { pmean }}$. An influence of $x_{\text {irr }}$ would be obvious, as irrigated areas should be less vulnerable to variability in precipitation. High $x_{\text {fert }}$ reduces the positive effect of $r_{\text {pmean }}$ in many regions. This also means that a reduction in $r_{\text {pmean }}$ has less impact when $x_{\text {fert }}$ is high. In France, farms with larger $x_{\text {mai }}$ and $y_{\text {mai }}$ benefit more from more precipitation. The effect of output and area of other arable crops and other agricultural activities varies per region. 
Table 2 The impact of climatic factors (external factors $r_{f}$ ) on total production $\left(\varepsilon_{y 1, f}\right)$ and factors that influence these impacts $(C)$

\begin{tabular}{|c|c|c|c|c|c|c|c|c|c|}
\hline & & Greece & Spain & Italy & France & Germany & Benelux & UK & Scand. \\
\hline$\alpha_{r \text { tmean }}$ & & 9.14 & 2.89 & -3.51 & -0.66 & 2.66 & -0.64 & 6.59 & 0.23 \\
\hline \multirow[t]{3}{*}{$C_{r \text { tmean }, m}$} & $y_{\text {mai }}$ & -0.19 & 0.26 & -0.09 & -1.94 & 0.07 & 1.62 & & \\
\hline & $y_{\text {othar }}$ & 0.09 & 0.11 & -2.00 & 0.00 & 0.07 & 0.04 & -0.03 & 0.02 \\
\hline & $y_{\text {othact }}$ & 0.10 & 0.09 & 0.22 & -0.36 & -0.19 & -0.17 & 0.25 & 0.28 \\
\hline \multirow[t]{8}{*}{$C_{r \text { tmean }, k}$} & $x_{\text {fert }}$ & -7.00 & -1.47 & 1.88 & 6.75 & 1.09 & 0.17 & 8.41 & -2.64 \\
\hline & $x_{\text {prot }}$ & 1.46 & 0.14 & 2.18 & 4.26 & -4.84 & 0.07 & -0.77 & 1.09 \\
\hline & $x_{\text {size }}$ & 0.60 & 1.60 & 0.03 & -6.67 & 1.26 & -0.39 & -4.76 & -0.51 \\
\hline & $x_{\text {irr }}$ & 2.48 & 0.06 & -0.13 & 0.00 & 0.00 & 0.00 & -0.01 & 0.00 \\
\hline & $x_{\text {cer }}$ & 2.35 & 0.00 & -2.99 & 4.42 & -0.02 & -1.76 & 1.10 & 0.94 \\
\hline & $x_{\text {mai }}$ & -1.31 & -0.06 & -0.03 & -3.70 & 0.02 & -0.28 & & \\
\hline & $x_{\text {othar }}$ & 0.34 & 0.18 & 0.22 & -0.56 & -0.14 & 0.95 & -0.16 & -0.11 \\
\hline & $x_{\text {othact }}$ & -0.24 & -0.07 & 0.03 & 0.63 & 0.20 & 0.40 & -0.61 & -0.10 \\
\hline \multirow[t]{4}{*}{$C_{r \text { tmean }, f}$} & $r_{\text {tmean }}$ & -6.96 & -3.61 & 1.43 & -4.80 & -3.01 & -0.48 & -4.74 & 0.01 \\
\hline & $r_{\text {pmean }}$ & -0.89 & -0.04 & 2.32 & 1.23 & 0.31 & 0.27 & -4.02 & 0.31 \\
\hline & $r_{\text {subs }}$ & 0.40 & -0.04 & 0.17 & 1.00 & 2.45 & 0.02 & -1.96 & 0.55 \\
\hline & $r_{\text {year }}$ & 0.09 & -0.21 & 0.10 & -0.17 & 0.05 & 0.08 & 0.59 & 0.01 \\
\hline$\varepsilon_{y 1, r \text { tmean }}$ & & 0.48 & -0.18 & -0.17 & -0.58 & -0.03 & -0.08 & -0.13 & 0.09 \\
\hline$\alpha_{r \text { pmean }}$ & & 1.85 & 0.07 & 0.40 & 1.98 & 0.62 & -1.23 & 0.13 & 0.04 \\
\hline \multirow[t]{3}{*}{$C_{r \text { pmean }, m}$} & $y_{\text {mai }}$ & 0.03 & -0.06 & 0.01 & 0.20 & -0.32 & 0.61 & & \\
\hline & $y_{\text {othar }}$ & 0.14 & 0.00 & -0.22 & 0.00 & -0.02 & 0.04 & 0.02 & 0.00 \\
\hline & $y_{\text {othact }}$ & -0.01 & -0.04 & 0.06 & 0.14 & 0.04 & -0.04 & 0.04 & 0.07 \\
\hline \multirow[t]{8}{*}{$C_{r \text { pmean }, k}$} & $x_{\text {fert }}$ & -1.84 & -0.05 & -1.31 & -1.72 & -0.27 & 0.31 & -2.90 & 1.28 \\
\hline & $x_{\text {prot }}$ & 0.93 & 0.02 & 0.70 & 0.46 & 0.87 & 0.00 & 0.96 & -0.80 \\
\hline & $x_{\text {size }}$ & -0.28 & -0.09 & 0.39 & 0.18 & -0.11 & -0.21 & 2.31 & -0.45 \\
\hline & $x_{\text {irr }}$ & -0.52 & -0.01 & 0.01 & 0.00 & 0.02 & 0.00 & 0.03 & 0.01 \\
\hline & $x_{\text {cer }}$ & 0.10 & 0.02 & -0.27 & 0.24 & 0.27 & -0.54 & -0.06 & 0.51 \\
\hline & $x_{\text {mai }}$ & 0.21 & 0.01 & 0.00 & 0.41 & -0.08 & -0.11 & & \\
\hline & $x_{\text {othar }}$ & 0.10 & -0.01 & -0.02 & -0.24 & 0.07 & 0.22 & -0.10 & -0.22 \\
\hline & $x_{\text {othact }}$ & 0.49 & 0.01 & 0.05 & -0.12 & 0.00 & 0.12 & -0.03 & -0.14 \\
\hline \multirow[t]{4}{*}{$C_{r \text { pmean }, f}$} & $r_{\text {tmean }}$ & -0.70 & -0.03 & 1.71 & 0.82 & 0.20 & 0.18 & -2.53 & 0.18 \\
\hline & $r_{\text {pmean }}$ & -0.57 & 0.03 & -1.39 & -1.45 & -1.19 & 0.85 & 1.91 & 0.14 \\
\hline & $r_{\text {subs }}$ & 0.16 & 0.10 & 0.03 & -0.93 & -0.26 & 0.02 & 0.44 & -0.39 \\
\hline & $r_{\text {year }}$ & -0.06 & 0.04 & -0.04 & 0.05 & 0.18 & -0.34 & -0.23 & -0.29 \\
\hline$\varepsilon_{y 1, r \mathrm{pm} \text { ean }}$ & & 0.03 & 0.02 & 0.10 & 0.03 & 0.03 & -0.09 & -0.01 & -0.06 \\
\hline
\end{tabular}

Parameters in bold are significant with $p<0.05$, in italic with $p<0.10$. Variables are described in Table 1 and measures are described in "Section 2.3". The elasticity $\varepsilon_{y 1, f}$ is defined in Eq. 4, and refers to the sum of the intercept $\alpha_{f}$ and interaction terms $C$ as presented in this table. Interaction terms $C$ represent the influence of outputs $y_{m}$, inputs $x_{j}$ and external factors $r_{f}$ on $\varepsilon_{y 1, f}$

\subsubsection{Policy impacts and time trends in production}

Subsidies can increase positive impacts of $r_{\text {tmean }}$ in Germany (Table 3; $C_{r \text { tmean, } r \text { subs }}=2.44$ ), but the impact on the overall production is small $\left(\varepsilon_{y 1 \text {,subs }}=0.003\right)$. So, subsidies can increase the adaptive capacity to climate change in some regions, while overall there is little impact. The negative intercept $\left(\alpha_{\text {subs }}=-0.57\right)$ is pushed to a slightly positive value by adding the complementary effects $x_{\text {fert }}, x_{\text {size }}$ and $r_{\text {tmean }}$.

In general, the overall impact of subsidies is relatively small, but is significantly influenced by inputs, outputs and external factors. The impact of these factors differs per 
Table 3 The impact of subsidies and time (external factors $\left.r_{f}\right)$ on total production $\left(\varepsilon_{y 1, f}\right)$ and factors that influence these impacts $(C)$

\begin{tabular}{|c|c|c|c|c|c|c|c|c|c|}
\hline & & Greece & Spain & Italy & France & Germany & Benelux & UK & Scandin \\
\hline$\alpha_{r \text { subs }}$ & & 0.23 & -0.05 & -0.05 & -0.20 & -0.57 & 0.02 & 0.32 & -0.85 \\
\hline \multirow[t]{3}{*}{$C_{r \text { subs }, m}$} & $y_{\text {mai }}$ & 0.03 & 0.00 & 0.01 & -0.02 & 0.07 & -0.02 & & \\
\hline & $y_{\text {othar }}$ & 0.31 & 0.02 & -0.01 & 0.00 & -0.01 & 0.00 & 0.00 & 0.01 \\
\hline & $y_{\text {othact }}$ & $-\mathbf{0 . 0 7}$ & 0.00 & 0.00 & 0.03 & -0.03 & -0.01 & 0.05 & 0.13 \\
\hline \multirow[t]{8}{*}{$C_{r \text { subs }, k}$} & $x_{\text {fert }}$ & 0.94 & -0.01 & 0.05 & 0.16 & 0.61 & -0.02 & 0.42 & 0.82 \\
\hline & $x_{\text {prot }}$ & -1.63 & -0.01 & -0.03 & 0.21 & -0.35 & -0.03 & -0.26 & 0.91 \\
\hline & $x_{\text {size }}$ & 0.47 & 0.05 & 0.03 & -0.22 & 0.29 & 0.05 & -0.20 & -1.43 \\
\hline & $x_{\text {irr }}$ & -0.18 & -0.01 & 0.00 & 0.00 & 0.00 & 0.00 & 0.00 & 0.01 \\
\hline & $x_{\text {cer }}$ & 0.16 & 0.01 & -0.04 & 0.18 & -0.25 & 0.01 & 0.16 & -0.25 \\
\hline & $x_{\text {mai }}$ & 0.28 & 0.00 & 0.00 & -0.03 & 0.02 & 0.00 & & \\
\hline & $x_{\text {othar }}$ & -0.38 & 0.00 & 0.00 & -0.02 & -0.19 & -0.01 & 0.01 & -0.25 \\
\hline & $x_{\text {othact }}$ & -0.01 & 0.00 & 0.00 & 0.02 & -0.05 & 0.00 & -0.30 & -0.24 \\
\hline \multirow[t]{4}{*}{$C_{r \text { subs }, f}$} & $r_{\text {tmean }}$ & 0.07 & -0.01 & 0.03 & 0.17 & 0.39 & 0.00 & -0.31 & 0.07 \\
\hline & $r_{\text {pmean }}$ & 0.04 & 0.03 & 0.01 & -0.23 & -0.06 & 0.01 & 0.11 & -0.09 \\
\hline & $r_{\text {subs }}$ & -0.22 & 0.00 & 0.00 & -0.08 & 0.18 & 0.01 & 0.04 & 1.23 \\
\hline & $r_{\text {year }}$ & -0.02 & -0.02 & -0.01 & 0.02 & -0.04 & -0.01 & -0.02 & -0.09 \\
\hline$\varepsilon_{y 1, r \text { subs }}$ & & 0.02 & -0.01 & -0.01 & -0.03 & 0.00 & 0.00 & 0.02 & -0.02 \\
\hline$\alpha_{r y e a r}$ & & -0.02 & 0.11 & 0.00 & 0.05 & -0.11 & 0.12 & 0.02 & 0.08 \\
\hline \multirow[t]{3}{*}{$C_{r \text { year }, m}$} & $y_{\text {mai }}$ & 0.00 & -0.01 & 0.00 & 0.00 & -0.02 & 0.05 & & \\
\hline & $y_{\text {othar }}$ & -0.06 & 0.01 & 0.02 & 0.00 & 0.00 & 0.02 & 0.00 & 0.00 \\
\hline & $y_{\text {othact }}$ & 0.00 & -0.01 & -0.01 & 0.01 & 0.00 & 0.00 & 0.01 & 0.01 \\
\hline \multirow[t]{8}{*}{$C_{r \text { year, } k}$} & $x_{\text {fert }}$ & -0.11 & 0.02 & -0.02 & -0.13 & 0.06 & 0.24 & -0.12 & 0.11 \\
\hline & $x_{\text {prot }}$ & 0.10 & -0.03 & -0.02 & 0.05 & 0.02 & -0.13 & 0.00 & 0.08 \\
\hline & $x_{\text {size }}$ & 0.15 & 0.00 & 0.01 & 0.04 & 0.04 & -0.07 & -0.02 & 0.03 \\
\hline & $x_{\mathrm{irr}}$ & 0.02 & 0.00 & 0.00 & 0.00 & 0.00 & 0.00 & 0.00 & 0.00 \\
\hline & $x_{\text {cer }}$ & -0.11 & 0.01 & 0.03 & 0.01 & 0.03 & 0.03 & 0.03 & -0.01 \\
\hline & $x_{\text {mai }}$ & -0.04 & 0.00 & 0.00 & 0.00 & 0.00 & -0.01 & & \\
\hline & $x_{\text {othar }}$ & 0.06 & 0.00 & 0.00 & 0.00 & $-\mathbf{0 . 0 3}$ & -0.05 & 0.00 & 0.02 \\
\hline & $x_{\text {othact }}$ & 0.03 & 0.01 & 0.01 & -0.03 & -0.02 & -0.02 & 0.05 & -0.02 \\
\hline \multirow[t]{3}{*}{$C_{r \text { year } f}$} & $r_{\text {tmean }}$ & 0.04 & -0.07 & 0.04 & -0.06 & 0.02 & 0.03 & 0.20 & 0.00 \\
\hline & $r_{\text {pmean }}$ & -0.03 & 0.02 & -0.02 & 0.03 & 0.09 & -0.18 & -0.12 & -0.13 \\
\hline & $r_{\text {subs }}$ & -0.05 & -0.03 & -0.01 & 0.03 & -0.08 & -0.01 & -0.03 & -0.18 \\
\hline$\varepsilon_{y 1, r \text { year }}$ & & 0.01 & 0.00 & 0.00 & -0.03 & 0.00 & 0.02 & 0.02 & -0.02 \\
\hline
\end{tabular}

Parameters in bold are significant with $p<0.05$, in italic with $p<0.10$. Variables are described in Table 1 and measures are described in "Section 2.3". The elasticity $\varepsilon_{y 1, f}$ is defined in Eq. 4, and refers to the sum of the intercept $\alpha_{f}$ and interaction terms $C$ as presented in this table. Interaction terms $C$ represent the influence of outputs $y_{m}$, inputs $x_{j}$ and external factors $r_{f}$ on $\varepsilon_{y 1, f}$.

region. Subsidies are more important (contribute more to production) on large farms $\left(C_{r \text { subs, } x \text { size }}\right)$ in Mediterranean regions and Germany, while less on large farms in Scandinavia. The impact of land uses differs, but the influence of subsidies generally decreases when the area of other arable crops $x_{\text {othar }}$ or area of other agricultural activities $x_{\text {othact }}$ increases. As subsidies are mainly supplied for cereal areas, this is according to expectations. Also obvious is that the influence of subsidies decreases in time. As the focus in the CAP switched from increasing food production to more environmental issues, it is not surprising that subsidies contribute less to production.

Production has changed little over time for the years considered (i.e. 1990-2003), but decreased slightly in France, Germany and Scandinavia. An increasing $r_{\text {pmean }}$ negatively 
Fig. 2 The impact of temperature $r_{\text {tmean }}$ on total production $y_{1}$ $\left(\varepsilon_{y 1, r \text { tmean }}\right)$ per region in relation to the average $r_{\text {tmean }}$. Note: averages are based on the farm type data included in the analysis. This average may differ from the averages based on regional temperatures. For example, in Germany more farms are located in relatively colder regions and therefore the average is lower than the average based on regional temperatures

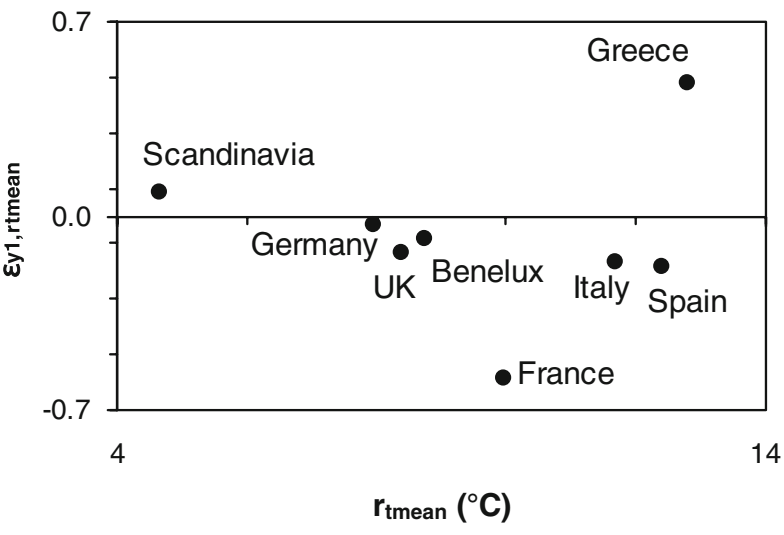

influences the time trend in production in the Benelux, Scandinavia, UK and Italy, and is positive for Germany. An increasing $r_{\text {tmean }}$ increases the time trend in the UK. The impact of subsidies on the time trend is negative, as was already observed. Furthermore, land uses and outputs influence the time trend significantly in Mediterranean regions. More $x_{\text {mai }}$ and $y_{\text {mai }}$ decrease the time trend. A larger $x_{\text {othact }}$ increases the time trend, while more output of other agricultural activities $y_{\text {othact }}$ (ceteris paribus, so with a constant area) has a negative effect. This implies that increasing areas for other agricultural activities has a positive impact, but where $y_{\text {othact }}$ is very high (other agricultural activities with a high output/ha, e.g. horticulture) this is not the case.

\subsection{Impacts of climate, subsidies and inputs on output composition}

\subsubsection{Climate and policy impacts on output composition}

Climate and subsidy changes have a different impact on different outputs and can hence influence output composition. Recall that for outputs, negative terms with respect to $y_{m}$ denote a greater contribution of output $y_{m}$ in total output relative to $y_{1}\left(y_{\text {cer }}\right)$. Positive crossterms thus reduce the contribution of output $y_{m}$ to total output when the associated variable increases.

Fig. 3 The impact of precipitation $r_{\text {pmean }}$ on total production $y_{1}$ $\left(\varepsilon_{y 1, r \text { pmean }}\right)$ per region in relation to the average $r_{\text {pmean }}$

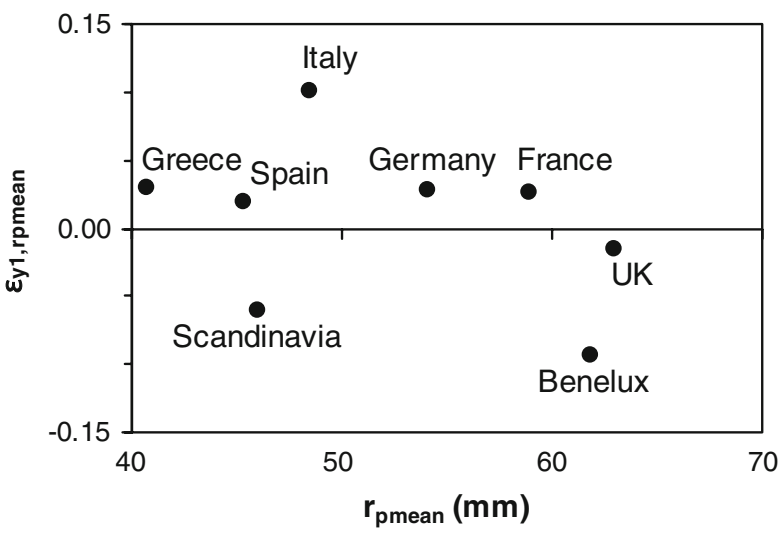


Table 4 The impact of other outputs, inputs and external factors $(C)$ on total output composition $\left(\varepsilon_{y 1, y m}\right.$; Eq. 5)

\begin{tabular}{|c|c|c|c|c|c|c|c|c|c|}
\hline & & Greece & Spain & Italy & France & Germany & Benelux & UK & Scandin. \\
\hline \multicolumn{2}{|l|}{$\alpha_{y \text { mai }}$} & -1.20 & -0.33 & -0.06 & -1.50 & -0.28 & 1.00 & & \\
\hline \multirow[t]{3}{*}{$C_{y \text { mai }, m}$} & $y_{\text {mai }}$ & -0.12 & -0.39 & -0.01 & 0.04 & 0.01 & -0.50 & & \\
\hline & $y_{\text {othar }}$ & -0.27 & -0.15 & 0.04 & 0.00 & -0.02 & 0.00 & & \\
\hline & $y_{\text {othact }}$ & -0.09 & -0.26 & -0.02 & -0.04 & 0.00 & -0.29 & & \\
\hline \multirow[t]{8}{*}{$C_{y \text { mai }, k}$} & $x_{\text {fert }}$ & 0.56 & 0.19 & 0.01 & 0.95 & 0.13 & 0.02 & & \\
\hline & $x_{\text {prot }}$ & -0.71 & 0.12 & -0.02 & 0.25 & 0.32 & -0.90 & & \\
\hline & $x_{\text {size }}$ & 2.09 & 0.27 & -0.09 & -0.60 & 0.08 & 0.68 & & \\
\hline & $x_{\mathrm{irr}}$ & 0.12 & -0.01 & 0.00 & 0.00 & -0.01 & 0.00 & & \\
\hline & $x_{\text {cer }}$ & 0.24 & 0.04 & 0.05 & -0.14 & -0.14 & 0.09 & & \\
\hline & $x_{\text {mai }}$ & -0.96 & 0.08 & 0.00 & 0.01 & 0.00 & 0.06 & & \\
\hline & $x_{\text {othar }}$ & -0.07 & -0.06 & 0.01 & -0.18 & -0.08 & 0.20 & & \\
\hline & $x_{\text {othact }}$ & -0.03 & -0.03 & 0.04 & -0.11 & -0.04 & -0.02 & & \\
\hline \multirow[t]{4}{*}{$C_{y \text { mai }, f}$} & $r_{\text {tmean }}$ & 0.59 & -0.13 & 0.05 & 1.34 & -0.02 & -0.40 & & \\
\hline & $r_{\text {pmean }}$ & -0.10 & 0.04 & 0.00 & -0.21 & 0.14 & -0.22 & & \\
\hline & $r_{\text {subs }}$ & -0.55 & 0.00 & -0.02 & 0.09 & -0.12 & 0.02 & & \\
\hline & $r_{\text {year }}$ & 0.03 & 0.02 & 0.01 & 0.00 & 0.02 & -0.03 & & \\
\hline \multicolumn{2}{|l|}{$\varepsilon_{y 1, y \mathrm{mai}}$} & -0.47 & -0.60 & -0.02 & -0.10 & -0.02 & -0.28 & & \\
\hline \multicolumn{2}{|l|}{$\alpha_{y \text { othar }}$} & -0.70 & -0.22 & 0.30 & -0.20 & -0.12 & -0.33 & -0.08 & 0.19 \\
\hline \multirow[t]{3}{*}{$C_{y \text { othar }, m}$} & $y_{\text {mai }}$ & 0.06 & 0.14 & -0.04 & 0.01 & 0.17 & -0.01 & & \\
\hline & $y_{\text {othar }}$ & 0.15 & -0.04 & 0.05 & 0.00 & -0.01 & -0.11 & 0.00 & 0.00 \\
\hline & $y_{\text {othact }}$ & 0.12 & 0.18 & 0.12 & 0.09 & 0.35 & 0.22 & 0.04 & 0.04 \\
\hline \multirow[t]{8}{*}{$C_{y \text { othar }, k}$} & $x_{\text {fert }}$ & 0.84 & -0.01 & 0.87 & 0.07 & 0.46 & 0.00 & 0.04 & 0.15 \\
\hline & $x_{\text {prot }}$ & 0.04 & 0.01 & -0.05 & -0.13 & -0.93 & -0.10 & -0.06 & 0.04 \\
\hline & $x_{\text {size }}$ & -2.18 & -0.26 & -0.45 & -0.38 & -1.01 & 0.06 & -0.09 & -0.59 \\
\hline & $x_{\text {irr }}$ & 0.03 & 0.00 & -0.02 & 0.00 & 0.00 & 0.00 & 0.01 & 0.00 \\
\hline & $x_{\text {cer }}$ & 0.08 & -0.01 & 0.42 & 0.46 & 0.88 & 0.07 & 0.08 & 0.44 \\
\hline & $x_{\text {mai }}$ & 0.45 & $-\mathbf{0 . 0 3}$ & -0.01 & 0.03 & 0.05 & 0.01 & & \\
\hline & $x_{\text {othar }}$ & 0.00 & 0.00 & 0.05 & -0.01 & -0.04 & -0.02 & 0.00 & 0.12 \\
\hline & $x_{\text {othact }}$ & -0.36 & -0.01 & -0.20 & -0.06 & 0.09 & -0.07 & 0.00 & 0.02 \\
\hline \multirow[t]{4}{*}{$C_{y \text { othar }, f}$} & $r_{\text {tmean }}$ & 0.06 & 0.05 & -1.13 & -0.01 & 0.15 & 0.03 & 0.07 & -0.06 \\
\hline & $r_{\text {pmean }}$ & 0.12 & 0.00 & -0.17 & -0.01 & -0.08 & 0.05 & -0.06 & 0.01 \\
\hline & $r_{\text {subs }}$ & 1.13 & 0.03 & -0.04 & 0.03 & -0.10 & 0.02 & 0.02 & -0.30 \\
\hline & $r_{\text {year }}$ & -0.10 & 0.01 & 0.03 & 0.00 & -0.01 & 0.04 & -0.01 & -0.04 \\
\hline \multicolumn{2}{|l|}{$\varepsilon_{y 1, y \text { othar }}$} & -0.26 & -0.14 & -0.26 & -0.12 & -0.13 & -0.14 & -0.04 & 0.01 \\
\hline \multicolumn{2}{|l|}{$\alpha_{\text {yothact }}$} & -0.28 & -0.06 & -0.26 & 0.18 & -0.06 & -0.08 & -0.51 & 0.06 \\
\hline \multirow[t]{3}{*}{$C_{y \text { othact }, m}$} & $y_{\text {mai }}$ & 0.03 & 0.23 & 0.02 & 0.05 & 0.01 & 0.61 & & \\
\hline & $y_{\text {othar }}$ & 0.16 & 0.17 & 0.16 & 0.02 & 0.12 & 0.15 & -0.01 & -0.01 \\
\hline & $y_{\text {othact }}$ & 0.00 & 0.00 & 0.00 & -0.18 & -0.01 & -0.17 & -0.22 & -0.11 \\
\hline \multirow[t]{8}{*}{$C_{y \text { othact }, k}$} & $x_{\text {fert }}$ & -0.11 & -0.19 & -0.30 & -0.31 & -0.72 & -0.14 & 0.35 & -0.17 \\
\hline & $x_{\text {prot }}$ & 0.18 & 0.01 & 0.04 & -0.11 & 0.23 & 0.37 & 0.12 & 0.37 \\
\hline & $x_{\text {size }}$ & -0.46 & -0.17 & -0.13 & 0.08 & -0.70 & -0.39 & -0.38 & -1.54 \\
\hline & $x_{\mathrm{irr}}$ & 0.29 & 0.00 & 0.01 & 0.00 & -0.02 & 0.00 & -0.09 & 0.01 \\
\hline & $x_{\text {cer }}$ & 0.11 & -0.08 & 0.24 & -0.37 & 1.11 & -0.48 & -0.47 & -0.09 \\
\hline & $x_{\text {mai }}$ & 0.21 & -0.05 & 0.01 & 0.14 & 0.01 & -0.11 & & \\
\hline & $x_{\text {othar }}$ & 0.03 & 0.00 & 0.00 & 0.26 & 0.01 & 0.13 & 0.04 & -0.13 \\
\hline & $x_{\text {othact }}$ & 0.09 & 0.01 & 0.00 & 0.01 & -0.03 & 0.06 & 0.18 & 0.03 \\
\hline \multirow[t]{3}{*}{$C_{y \text { othact }, f}$} & $r_{\text {tmean }}$ & 0.09 & 0.04 & 0.16 & -0.34 & -0.14 & -0.09 & 0.17 & 0.29 \\
\hline & $r_{\text {pmean }}$ & -0.01 & $-\mathbf{0 . 0 3}$ & 0.06 & 0.20 & 0.05 & -0.03 & 0.05 & 0.13 \\
\hline & $r_{\text {subs }}$ & -0.36 & -0.01 & 0.00 & 0.18 & -0.13 & -0.03 & 0.23 & 1.00 \\
\hline
\end{tabular}


Table 4 (continued)

\begin{tabular}{|c|c|c|c|c|c|c|c|c|c|}
\hline & & Greece & Spain & Italy & France & Germany & Benelux & UK & Scandin. \\
\hline & $r_{\text {year }}$ & -0.01 & -0.01 & -0.01 & 0.01 & 0.00 & 0.00 & 0.01 & 0.04 \\
\hline$\varepsilon_{y 1, y \text { othact }}$ & & -0.04 & -0.11 & -0.01 & -0.18 & -0.28 & -0.19 & -0.55 & -0.12 \\
\hline$\varepsilon_{D o, y 1}$ & & -0.23 & -0.14 & -0.71 & -0.59 & -0.57 & -0.40 & -0.42 & -0.89 \\
\hline
\end{tabular}

Parameters in bold are significant with $p<0.05$, in italic with $p<0.10$.

We observe in Table 4 that output elasticities $\varepsilon_{y 1, m}$ are indeed negative for all outputs in all regions (except $y_{\text {othar }}$ in Scandinavia, for which output is very small), thus more $y_{m}$ will yield more total output. In most regions the impact of output from cereals $\left(\varepsilon_{D o, y 1}\right)$ is large relative to other outputs. So an increase in cereal yields (cereal output with constant area), has more impact on total output than increases in yields of other products. Maize output has a larger impact in Spain and Greece, while in the UK other agricultural activities have quite a large influence.

In France, maize output is significantly reduced relative to other cereals when the temperature $r_{\text {tmean }}$ is higher (this can also be observed in Table $2, C_{r \text { tmean,ymai }}$ ). The contribution of output of other agricultural activities $y_{\text {othact }}$ rises with increasing $r_{\text {tmean }}$. In Italy the contribution of the output of other arable crops $y_{\text {othar }}$ significantly increases with $r_{\text {tmean }}$, while $y_{\text {othact }}$ decreases. Also in Scandinavia $y_{\text {othact }}$ decreases relative to cereals with increasing temperatures. Precipitation $r_{\text {pmean }}$ has a significant influence on output composition in all regions, except for Greece and Benelux. More $r_{\text {pmean }}$ decreases maize output relative to other cereals in Spain and Germany, and increases it in France. Maize is thus less influenced by lower precipitation in Spain and Greece, probably because maize is more often irrigated. Although not significant, the opposite effect of irrigate area $x_{\text {irr }}$ confirms this. Irrigated maize in France may be more dependent on fluctuations in water available for irrigation. Output of other arable crops $y_{\text {othar }}$ is increased with a high $r_{\text {pmean }}$ in Italy, UK and Scandinavia and output of other agricultural activities $y_{\text {othact }}$ increases in Scandinavia and decreases in Italy and France.

Subsidies $r_{\text {subs }}$ favour maize production and other agricultural activities relative to cereals in Mediterranean regions. Output of other arable crops is decreased in Greece and Spain, but the opposite is the case in Italy. In Scandinavia more subsidies lead to a lower contribution of $y_{\text {othact }}$. Over time, the contribution of maize output has reduced in Mediterranean regions. The influence of time $r_{\text {year }}$ on the share of $y_{\text {othar }}$ and $y_{\text {othact }}$ differs per region.

\subsubsection{Contribution of inputs and outputs to output composition}

Also the influence of inputs differs per output. On farms with higher fertilizer use $x_{\text {fert }}$, an increase in maize output $y_{\text {mai }}$ has a smaller impact on total production (Table $4 ; C_{y \text { mai } x \text { fert }}$ ). This is also the case for the output of other arable crops $y_{\text {othar }}$, but the opposite is true for the output of other agricultural activities $y_{\text {othact }}$. For $y_{\text {mai }}$ and $y_{\text {othar }}$ this is according to agronomic relationships, with a decreasing marginal product when more fertilizers are used (e.g. Mengel 1983). Other agricultural activities are a mix of livestock, permanent cropping, horticulture and other practices; the positive impact suggests more output from fertilizer intensive activities.

An increase in $y_{\text {othar }}$ and $y_{\text {othact }}$ has more effect on total output on farms with a larger economic size. This is variable for $y_{\text {mai }}$. In Greece, $y_{\text {mai }}$ contribution can especially increase 
on small farms (positive $C_{y \text { mai, } x \text { size }}$ ). Irrigation has a small effect on changes in output composition, but significant effects are observed. Increases in $x_{\text {irr }}$ reduce the $\varepsilon_{y 1, y \text { mai }}$ in Italy and France (an increase in $y_{\text {mai }}$ has less effect on total output), while increasing it in Germany. Also for $x_{\text {othact }}$ the effect is negative in these regions.

More area for a specific output doesn't necessarily lead to more relative output. In Greece and Italy more maize area $x_{\text {mai }}$ will raise the contribution of $y_{\text {mai }}$, but in Spain, France and Benelux it will reduce the contribution. Also for other arable crops and other agricultural activities more area often reduces the marginal product.

Outputs can also complement or substitute each other. Generally, the share of maize output increases more when also $y_{\text {othar }}$ and $y_{\text {othact }}$ increase. The elasticity of $y_{\text {othar }}$ and $y_{\text {othact }}$ however decrease relative to other cereals with higher $y_{\text {mai }}$, while $y_{\text {othar }}$ and $y_{\text {othact }}$ also negatively influence each other.

\subsection{Influence of inputs on production and adaptation strategies}

\subsubsection{Intensity, size and adaptation}

The contribution of fertilizer use, crop protection use, economic size, irrigation and land uses to production can be observed from $\varepsilon_{y 1, k}$ (Tables 5 and 6). The interaction terms $C_{k f}$ indicate whether $x_{k}$ is changed as a result of adaptation to climate, subsidies or time in general.

A higher use of fertilizers $x_{\text {fert }}$ has a positive contribution to outputs in most regions, but negative in the UK and Scandinavia. A negative contribution suggests that fertilizers are used in abundance. In both regions the impact of climate variables is significant, but contrasting. At a higher temperature $r_{\text {tmean }}$ the contribution of $x_{\text {fert }}$ increases in the UK, and also in Italy and France. In Scandinavia the impact of $x_{\text {fert }}$ decreases at higher $r_{\text {tmean }}$. In most regions a low precipitation $r_{\text {pmean }}$ also increases the contribution of $x_{\text {fert }}$, suggesting that fertilizer use has less effect with more rainfall. $C_{x \text { fert } x c e r}$ is very high in Greece, Italy and France, implying that the area of cereals has a positive impact on the impact of fertilizers on total output. Subsidies generally increase the importance of $x_{\text {fert }}$. There is relatively little change in time, but the impact of time $r_{\text {year }}$ on $\varepsilon_{y 1, x f e r t}$ is significantly negative in France and positive in Benelux.

Crop protection use mainly contributes to production in Mediterranean regions where permanent cropping (part of $x_{\text {othact }}$ ) is high. In other regions none of the land uses really seems to benefit from more crop protection products $x_{\text {prot }}$. The effect of climatic conditions is quite substantial however. Both at higher $r_{\text {tmean }}$ and higher $r_{\text {pmean }}$ an increasing $x_{\text {prot }}$ has more effect. This suggests that a higher use of crop production products is applied as an adaptation strategy to more pests and diseases occurring at higher temperatures and more precipitation. In Germany the importance of $x_{\text {prot }}$ however reduces with higher $r_{\text {tmean }}$. The contribution of $x_{\text {prot }}$ also decreases in most regions when subsidies increase.

In all regions farm size has a positive impact on total production $\left(\varepsilon_{y 1, x \mathrm{size}}\right)$. The contribution of $x_{\text {size }}$ rises at an increasing rate $\left(C_{x \text { size, } x \text { size }}\right)$. In Greece and Spain, the intercept is negative, but is pushed to a positive value by other effects. In Greece $x_{\text {prot }}$ and $r_{\text {subs }}$ are complementary with $x_{\text {size }}$; in Spain $x_{\text {fert }}$ and $r_{\text {subs }}$ raise the effect of $x_{\text {size }}$, while also $r_{\text {tmean }}$ has a high value. A higher cereal area $x_{\text {cer }}$, decreases the effect of increasing farm size; for other land uses the effect varies per region. In France, at high $r_{\text {tmean }}$ an increase in $x_{\text {size }}$ has less effect. Only in the UK and Italy $r_{\text {pmean }}$ has an impact and it indicates more returns to increasing $x_{\text {size }}$ when rainfall is high. Higher subsidies contribute to the positive effect of $x_{\text {size }}$ in Mediterranean regions and Germany; in Scandinavia subsidies decrease the elasticity of $x_{\text {size }}$. 
Table 5 Contribution of inputs to production $\left(\varepsilon_{y 1, k}\right.$; Eq. 6) and adaptation strategies $\left(C_{k f}\right)$

\begin{tabular}{|c|c|c|c|c|c|c|c|c|c|}
\hline & & Greece & Spain & Italy & France & Germany & Benelux & UK & Scandin. \\
\hline$\alpha_{x \text { fert }}$ & & 1.81 & 0.26 & 0.19 & 0.29 & 0.37 & -0.39 & -1.28 & 0.04 \\
\hline \multirow[t]{3}{*}{$C_{x \text { fert }, m}$} & $y_{\text {mai }}$ & -0.04 & -0.08 & 0.00 & -0.23 & -0.07 & -0.02 & & \\
\hline & $y_{\text {othar }}$ & 0.24 & 0.00 & 0.31 & 0.00 & 0.03 & 0.00 & 0.00 & -0.01 \\
\hline & $y_{\text {othact }}$ & -0.02 & -0.08 & -0.08 & -0.06 & -0.16 & -0.05 & 0.09 & -0.02 \\
\hline \multirow[t]{8}{*}{$C_{x \mathrm{fert}, k}$} & $x_{\text {fert }}$ & -1.05 & 0.04 & -0.65 & -0.78 & -1.68 & 0.93 & 0.05 & -0.34 \\
\hline & $x_{\text {prot }}$ & -0.53 & 0.02 & 0.00 & -0.04 & -0.36 & -0.08 & 0.08 & -0.27 \\
\hline & $x_{\text {size }}$ & 0.21 & 0.20 & -0.16 & -0.13 & 1.33 & -0.35 & -0.56 & -0.57 \\
\hline & $x_{\text {irr }}$ & -0.20 & 0.00 & 0.03 & 0.00 & -0.02 & -0.02 & 0.01 & 0.00 \\
\hline & $x_{\mathrm{cer}}$ & 0.85 & 0.00 & 0.36 & 0.49 & -0.07 & -0.13 & 0.06 & -0.05 \\
\hline & $x_{\text {mai }}$ & -0.33 & 0.02 & -0.01 & -0.51 & -0.01 & 0.00 & & \\
\hline & $x_{\text {othar }}$ & 0.02 & 0.00 & 0.00 & -0.19 & -0.16 & -0.11 & 0.09 & 0.18 \\
\hline & $x_{\text {othact }}$ & -0.09 & -0.02 & 0.03 & 0.44 & 0.02 & 0.03 & 0.44 & 0.08 \\
\hline \multirow[t]{4}{*}{$C_{x \mathrm{fert}, f}$} & $r_{\text {tmean }}$ & -1.36 & -0.30 & 0.38 & 1.14 & 0.18 & 0.03 & 1.36 & -0.38 \\
\hline & $r_{\text {pmean }}$ & -0.46 & -0.01 & -0.36 & -0.43 & -0.07 & 0.08 & -0.75 & 0.31 \\
\hline & $r_{\text {subs }}$ & 1.00 & -0.01 & 0.05 & 0.16 & 0.64 & -0.02 & 0.43 & 0.88 \\
\hline & $r_{\text {year }}$ & -0.05 & 0.01 & -0.01 & -0.06 & 0.03 & 0.11 & -0.06 & 0.06 \\
\hline \multicolumn{2}{|l|}{$\varepsilon_{y 1, x \text { fert }}$} & 0.01 & 0.05 & 0.07 & 0.07 & 0.00 & 0.03 & -0.04 & -0.09 \\
\hline \multicolumn{2}{|l|}{$\alpha_{x \text { prot }}$} & 0.03 & 0.00 & -0.68 & -0.87 & -0.18 & 0.01 & 0.17 & -0.17 \\
\hline \multirow[t]{3}{*}{$C_{x p r o t, m}$} & $y_{\text {mai }}$ & 0.05 & -0.05 & 0.01 & -0.06 & -0.19 & 0.65 & & \\
\hline & $\mathrm{y}_{\text {othar }}$ & 0.01 & 0.01 & -0.02 & 0.00 & -0.07 & -0.02 & 0.00 & 0.00 \\
\hline & $\mathrm{y}_{\text {othact }}$ & 0.04 & 0.01 & 0.01 & -0.02 & 0.05 & 0.13 & 0.03 & 0.05 \\
\hline \multirow[t]{8}{*}{$C_{x p r o t, k}$} & $x_{\text {fert }}$ & -0.54 & 0.02 & 0.00 & -0.04 & -0.37 & -0.08 & 0.08 & -0.30 \\
\hline & $x_{\text {prot }}$ & -0.08 & 0.02 & 0.09 & 0.88 & 3.28 & 0.44 & -1.09 & 0.07 \\
\hline & $x_{\text {size }}$ & 1.28 & -0.04 & 0.10 & -0.20 & -0.94 & -0.55 & 1.02 & -0.31 \\
\hline & $x_{\text {irr }}$ & 0.34 & 0.00 & 0.01 & 0.00 & -0.02 & 0.01 & 0.00 & 0.00 \\
\hline & $x_{\text {cer }}$ & -0.28 & 0.06 & -0.02 & -0.55 & -0.39 & -0.40 & 0.10 & 0.06 \\
\hline & $x_{\text {mai }}$ & 0.41 & 0.01 & 0.00 & -0.11 & -0.04 & -0.13 & & \\
\hline & $x_{\text {othar }}$ & -0.44 & -0.02 & -0.04 & 0.19 & 0.05 & 0.17 & 0.03 & -0.15 \\
\hline & $x_{\text {othact }}$ & 0.51 & 0.02 & 0.04 & -0.09 & 0.01 & 0.02 & -0.08 & -0.21 \\
\hline \multirow[t]{4}{*}{$C_{x p r o t, f}$} & $r_{\text {tmean }}$ & 0.29 & 0.03 & 0.46 & 0.74 & -0.82 & 0.01 & -0.14 & 0.17 \\
\hline & $r_{\text {pmean }}$ & 0.24 & 0.01 & 0.20 & 0.12 & 0.23 & 0.00 & 0.28 & -0.21 \\
\hline & $r_{\text {subs }}$ & -1.79 & -0.01 & -0.03 & 0.22 & -0.38 & -0.03 & -0.30 & 1.07 \\
\hline & $r_{\text {year }}$ & 0.05 & -0.02 & -0.01 & 0.03 & 0.01 & -0.06 & 0.00 & 0.05 \\
\hline \multicolumn{2}{|l|}{$\varepsilon_{y 1, x \text { prot }}$} & 0.12 & 0.04 & 0.11 & 0.21 & 0.24 & 0.16 & 0.11 & 0.12 \\
\hline \multicolumn{2}{|l|}{$\alpha_{x \text { size }}$} & -0.67 & -0.28 & 0.46 & 1.85 & 0.07 & 0.87 & 1.05 & 1.17 \\
\hline \multirow[t]{3}{*}{$C_{x \text { size }, m}$} & $y_{\text {mai }}$ & -0.19 & -0.15 & 0.04 & 0.21 & -0.06 & -0.64 & & \\
\hline & $y_{\text {othar }}$ & -0.89 & -0.16 & -0.23 & -0.02 & -0.10 & 0.02 & 0.01 & 0.04 \\
\hline & $y_{\text {othact }}$ & -0.13 & -0.11 & -0.05 & 0.02 & -0.22 & -0.17 & -0.13 & -0.29 \\
\hline \multirow[t]{8}{*}{$C_{x \text { size }, k}$} & $x_{\text {fert }}$ & 0.29 & 0.29 & -0.23 & -0.19 & 1.85 & -0.47 & -0.80 & -0.79 \\
\hline & $x_{\text {prot }}$ & 1.75 & -0.05 & 0.13 & -0.28 & -1.27 & -0.72 & 1.29 & -0.39 \\
\hline & $x_{\text {size }}$ & 0.44 & 0.20 & 0.25 & 0.85 & 0.83 & 1.11 & 0.15 & 3.37 \\
\hline & $x_{\text {irr }}$ & 0.22 & -0.01 & -0.03 & 0.00 & 0.06 & -0.01 & 0.09 & -0.01 \\
\hline & $x_{\mathrm{cer}}$ & -0.66 & -0.08 & -0.54 & -0.66 & -1.66 & 0.42 & -0.37 & -1.22 \\
\hline & $x_{\text {mai }}$ & -1.48 & 0.04 & 0.02 & 0.42 & -0.03 & 0.11 & & \\
\hline & $x_{\text {othar }}$ & 0.67 & 0.01 & -0.03 & -0.05 & 0.33 & -0.16 & $-\mathbf{0 . 1 0}$ & 0.31 \\
\hline & $x_{\text {othact }}$ & -0.05 & -0.03 & 0.11 & -0.15 & -0.11 & -0.01 & 0.01 & 0.30 \\
\hline \multirow[t]{4}{*}{$C_{x \text { size }, f}$} & $r_{\text {tmean }}$ & 0.17 & 0.45 & 0.01 & -1.59 & 0.29 & -0.09 & -1.09 & -0.10 \\
\hline & $r_{\text {pmean }}$ & -0.10 & -0.03 & 0.15 & 0.06 & -0.04 & -0.07 & 0.84 & -0.15 \\
\hline & $r_{\text {subs }}$ & 0.70 & 0.07 & 0.05 & -0.32 & 0.42 & 0.05 & -0.30 & -2.14 \\
\hline & $r_{\text {year }}$ & 0.10 & 0.00 & 0.00 & 0.03 & 0.03 & -0.05 & -0.02 & 0.02 \\
\hline
\end{tabular}


Table 5 (continued)

\begin{tabular}{|c|c|c|c|c|c|c|c|c|c|}
\hline & & Greece & Spain & Italy & France & Germany & Benelux & UK & Scandin. \\
\hline \multicolumn{2}{|l|}{$\varepsilon_{y 1, x \text { size }}$} & 0.18 & 0.14 & 0.13 & 0.17 & 0.38 & 0.21 & 0.64 & 0.13 \\
\hline \multicolumn{2}{|l|}{$\alpha_{x \text { irr }}$} & -0.83 & 0.01 & 0.09 & 0.02 & -0.02 & -0.03 & -0.07 & -0.08 \\
\hline \multirow[t]{3}{*}{$C_{x \mathrm{irr}, m}$} & $y_{\text {mai }}$ & -0.01 & 0.01 & -0.01 & 0.02 & -0.01 & -0.01 & & \\
\hline & $y_{\text {othar }}$ & 0.01 & 0.00 & -0.03 & 0.00 & 0.00 & 0.00 & 0.00 & 0.00 \\
\hline & $y_{\text {othact }}$ & 0.10 & 0.01 & 0.01 & -0.02 & 0.01 & 0.00 & 0.08 & 0.01 \\
\hline \multirow[t]{8}{*}{$C_{x \mathrm{irr}, k}$} & $x_{\text {fert }}$ & -0.34 & 0.01 & 0.15 & 0.03 & 0.05 & 0.16 & -0.05 & 0.04 \\
\hline & $x_{\text {prot }}$ & 0.54 & 0.00 & 0.03 & -0.10 & 0.05 & -0.10 & 0.00 & 0.00 \\
\hline & $x_{\text {size }}$ & 0.26 & -0.02 & -0.11 & 0.07 & -0.14 & 0.03 & -0.25 & -0.05 \\
\hline & $x_{\mathrm{irr}}$ & -0.05 & 0.01 & 0.00 & 0.00 & 0.00 & 0.00 & 0.01 & 0.00 \\
\hline & $x_{\mathrm{cer}}$ & 0.52 & 0.00 & -0.02 & -0.08 & 0.02 & 0.01 & 0.22 & -0.02 \\
\hline & $x_{\text {mai }}$ & -0.11 & 0.00 & 0.00 & 0.03 & 0.00 & 0.00 & & \\
\hline & $x_{\text {othar }}$ & -0.26 & 0.00 & 0.00 & 0.00 & 0.02 & -0.02 & 0.01 & 0.02 \\
\hline & $x_{\text {othact }}$ & -0.12 & 0.00 & 0.00 & 0.01 & 0.02 & -0.05 & 0.06 & -0.06 \\
\hline \multirow[t]{4}{*}{$C_{x \mathrm{irr}, f}$} & $r_{\text {tmean }}$ & 0.81 & 0.03 & -0.13 & 0.00 & 0.00 & 0.00 & 0.01 & 0.00 \\
\hline & $r_{\text {pmean }}$ & -0.22 & 0.00 & 0.02 & 0.00 & -0.02 & 0.00 & -0.03 & 0.03 \\
\hline & $r_{\text {subs }}$ & -0.33 & -0.02 & 0.01 & 0.01 & 0.01 & 0.01 & 0.01 & 0.12 \\
\hline & $r_{\text {year }}$ & 0.02 & 0.00 & 0.00 & 0.00 & 0.00 & 0.00 & 0.00 & 0.00 \\
\hline$\varepsilon_{y 1, x i r r}$ & & 0.01 & 0.01 & 0.00 & 0.00 & 0.00 & 0.01 & 0.00 & 0.01 \\
\hline
\end{tabular}

Parameters in bold are significant with $p<0.05$, in italic with $p<0.10$.

An increase in irrigated area can only slightly change total output, but the $\varepsilon_{y 1, x i r r}$ is significantly influenced by many factors. In Greece, at higher $r_{\text {tmean }}$ and lower $r_{\text {pmean }}$ the contribution increases more. Irrigation is thus an important adaptation option here. The low elasticity of $x_{\text {irr }}$ in e.g. Spain and Italy is surprising, but interesting. It implies that a change in irrigated area has a small impact on total production. The intercept $\left(\alpha_{x i r r}\right)$ and own crosseffect $\left(C_{\text {xirr,xirr }}\right)$ are positive, but are adapted by other factors. In Italy, at higher $r_{\text {tmean }}$ increasing $x_{\text {irr }}$ reduces impact on total output. Hence, irrigation seems not a good adaptation strategy to higher temperatures in Italy. In Spain, climatic conditions have a small effect, but subsidies decrease the impact of $x_{\text {irr }}$. Also in other regions the effects of climate are small; other effects differ per region but can be large.

\subsubsection{Land use and adaptation}

The type of land use on a farm has a large influence on agricultural production (Table 6). This is not surprising, but of particular interest here is how land use is changing due to different drivers. It should be noted that the homogeneity of groups of land uses $x_{k}$ is different. Maize area $x_{\text {mai }}$ is distinguished separately, other cereals $x_{\text {cer }}$ are a relatively homogenous group, but within the groups of other arable crops $x_{\text {othar }}$ and other agricultural activities $x_{\text {othact }}$ heterogeneity can be large. So, if within the group $x_{\text {othact }}$ a change in permanent cropping area contributes highly and a change in area for specific livestock activities contributes little to total output, the average $\varepsilon_{y 1, \text { xothact }}$ can be close to zero. For our purpose, to look at these activities in relation to arable cropping this grouping suffices however.

The elasticities of land uses are similar to elasticities of associated $y_{m}$. Only in Mediterranean regions and in France, there is a relationship with climatic conditions. Effects differ however; e.g. an increase in $x_{\text {cer }}$ has more effect at high $r_{\text {tmean }}$ and high $r_{\text {pmean }}$ 
Table 6 Contribution of land uses $\left(\varepsilon_{y 1, k}\right.$; Eq. 6) to production and related adaptation strategies $\left(C_{k f}\right)$

\begin{tabular}{|c|c|c|c|c|c|c|c|c|c|}
\hline & & Greece & Spain & Italy & France & Germany & Benelux & UK & Scandin. \\
\hline \multicolumn{2}{|l|}{$\alpha_{x \mathrm{cer}}$} & -1.58 & 0.46 & 1.34 & -0.66 & 0.72 & 2.22 & 0.72 & 1.30 \\
\hline \multirow[t]{3}{*}{$C_{x \mathrm{xer}, m}$} & $y_{\text {mai }}$ & -0.03 & -0.05 & -0.04 & 0.06 & 0.14 & -0.14 & & \\
\hline & $y_{\text {othar }}$ & 0.05 & -0.01 & 0.36 & 0.03 & 0.12 & 0.04 & -0.01 & -0.04 \\
\hline & $y_{\text {othact }}$ & 0.05 & -0.11 & 0.16 & -0.12 & 0.44 & -0.35 & -0.22 & -0.02 \\
\hline \multirow{8}{*}{$C_{x \mathrm{cer}, k}$} & $x_{\text {fert }}$ & 1.78 & 0.01 & 0.86 & 0.86 & -0.12 & -0.28 & 0.11 & -0.09 \\
\hline & $x_{\text {prot }}$ & -0.57 & 0.17 & -0.04 & -0.95 & -0.68 & -0.87 & 0.18 & 0.08 \\
\hline & $x_{\text {size }}$ & -0.98 & -0.19 & -0.91 & -0.82 & -2.11 & 0.70 & -0.51 & -1.39 \\
\hline & $x_{\mathrm{irr}}$ & 0.65 & 0.00 & -0.01 & 0.01 & -0.01 & 0.00 & -0.11 & 0.00 \\
\hline & $x_{\mathrm{cer}}$ & 0.24 & 0.24 & 0.24 & 0.24 & 0.24 & 0.24 & 0.24 & 0.24 \\
\hline & $x_{\text {mai }}$ & -0.26 & 0.00 & -0.01 & 0.08 & 0.04 & 0.01 & & \\
\hline & $x_{\text {othar }}$ & -0.04 & -0.09 & 0.09 & 0.09 & -0.12 & 0.46 & 0.01 & 0.23 \\
\hline & $x_{\text {othact }}$ & -0.40 & -0.05 & -0.23 & -0.24 & 0.02 & -0.03 & 0.17 & 0.20 \\
\hline \multirow{4}{*}{$C_{x \mathrm{cer}_{2} f}$} & $r_{\text {tmean }}$ & 0.95 & 0.00 & -1.43 & 1.32 & -0.01 & -0.67 & 0.35 & 0.21 \\
\hline & $r_{\text {pmean }}$ & 0.05 & 0.02 & -0.17 & 0.11 & 0.12 & -0.30 & -0.03 & 0.20 \\
\hline & $r_{\text {subs }}$ & 0.34 & 0.04 & -0.09 & 0.33 & -0.46 & 0.01 & 0.33 & -0.42 \\
\hline & $r_{\text {year }}$ & -0.11 & 0.02 & 0.04 & 0.01 & 0.03 & 0.04 & 0.03 & -0.01 \\
\hline \multicolumn{2}{|l|}{$\varepsilon_{y 1, x \mathrm{cer}}$} & 0.17 & 0.46 & 0.14 & 0.34 & -1.65 & 1.05 & 1.26 & 0.50 \\
\hline \multicolumn{2}{|l|}{$\alpha_{x \text { mai }}$} & 1.57 & 0.45 & 0.12 & 2.06 & 0.36 & -1.45 & & \\
\hline \multirow[t]{3}{*}{$C_{x \mathrm{mai}, m}$} & $y_{\text {mai }}$ & 0.17 & 0.49 & 0.01 & -0.01 & -0.01 & 0.51 & & \\
\hline & $y_{\text {othar }}$ & 0.36 & 0.22 & -0.04 & 0.00 & 0.03 & -0.03 & & \\
\hline & $y_{\text {othact }}$ & 0.12 & 0.36 & 0.02 & 0.07 & 0.03 & 0.42 & & \\
\hline \multirow[t]{8}{*}{$C_{x \mathrm{mai}, k}$} & $x_{\text {fert }}$ & -0.92 & -0.35 & -0.04 & -1.51 & -0.15 & -0.04 & & \\
\hline & $x_{\text {prot }}$ & 1.11 & -0.13 & 0.02 & -0.31 & -0.43 & 1.45 & & \\
\hline & $x_{\text {size }}$ & -2.96 & $-\mathbf{0 . 3 9}$ & 0.13 & 0.88 & -0.20 & -0.99 & & \\
\hline & $x_{\text {irr }}$ & -0.18 & 0.01 & -0.01 & 0.00 & 0.01 & 0.00 & & \\
\hline & $x_{\text {cer }}$ & -0.35 & 0.02 & -0.04 & 0.13 & 0.25 & -0.04 & & \\
\hline & $x_{\text {mai }}$ & 1.19 & -0.07 & 0.00 & 0.04 & -0.01 & -0.05 & & \\
\hline & $x_{\text {othar }}$ & 0.13 & 0.09 & -0.01 & 0.25 & 0.10 & -0.31 & & \\
\hline & $x_{\text {othact }}$ & 0.03 & 0.04 & -0.07 & 0.14 & 0.06 & 0.03 & & \\
\hline \multirow[t]{4}{*}{$C_{x \text { mai, } f}$} & $r_{\text {tmean }}$ & -0.72 & 0.19 & -0.05 & -1.83 & 0.04 & 0.56 & & \\
\hline & $r_{\text {pmean }}$ & 0.15 & -0.06 & -0.01 & 0.30 & -0.20 & 0.32 & & \\
\hline & $r_{\text {subs }}$ & 0.85 & 0.00 & 0.03 & -0.10 & 0.18 & -0.03 & & \\
\hline & $r_{\text {year }}$ & -0.05 & -0.02 & -0.01 & -0.01 & -0.02 & 0.05 & & \\
\hline \multicolumn{2}{|l|}{$\varepsilon_{y 1, \text { mai }}$} & 0.51 & 0.87 & 0.03 & 0.11 & 0.04 & 0.40 & & \\
\hline \multicolumn{2}{|l|}{$\alpha_{x o t h a r}$} & 0.40 & -0.05 & -0.05 & 0.03 & 0.15 & -0.41 & -0.10 & 0.02 \\
\hline \multirow[t]{3}{*}{$C_{x \text { othar }, m}$} & $y_{\text {mai }}$ & 0.01 & 0.06 & -0.01 & 0.08 & 0.08 & -0.24 & & \\
\hline & $y_{\text {othar }}$ & 0.00 & 0.00 & 0.03 & 0.00 & 0.00 & -0.01 & 0.00 & -0.01 \\
\hline & $y_{\text {othact }}$ & 0.01 & 0.00 & 0.00 & 0.08 & 0.00 & 0.07 & 0.02 & -0.03 \\
\hline \multirow[t]{8}{*}{$C_{x \mathrm{othar}, k}$} & $x_{\text {fert }}$ & 0.03 & -0.01 & 0.00 & -0.34 & -0.27 & -0.18 & 0.23 & 0.33 \\
\hline & $x_{\text {prot }}$ & -0.78 & -0.03 & -0.07 & 0.32 & 0.08 & 0.27 & 0.07 & -0.23 \\
\hline & $x_{\text {size }}$ & 0.87 & 0.02 & -0.04 & -0.06 & 0.40 & -0.20 & -0.17 & 0.39 \\
\hline & $x_{\mathrm{irr}}$ & -0.28 & 0.00 & 0.00 & 0.00 & -0.01 & 0.00 & 0.00 & 0.00 \\
\hline & $x_{\text {cer }}$ & -0.03 & -0.06 & 0.07 & 0.09 & -0.11 & 0.34 & 0.02 & 0.25 \\
\hline & $x_{\mathrm{mai}}$ & 0.09 & -0.01 & 0.00 & 0.15 & 0.02 & 0.04 & & \\
\hline & $x_{\text {othar }}$ & 0.06 & 0.02 & 0.03 & -0.03 & -0.01 & 0.03 & 0.00 & -0.14 \\
\hline & $x_{\text {othact }}$ & 0.21 & 0.01 & 0.01 & -0.02 & 0.00 & -0.02 & 0.04 & 0.02 \\
\hline \multirow[t]{4}{*}{$C_{\text {xothar,f }}$} & $r_{\text {tmean }}$ & 0.12 & 0.08 & 0.08 & -0.17 & -0.04 & 0.27 & -0.06 & -0.03 \\
\hline & $r_{\text {pmean }}$ & 0.04 & 0.00 & -0.01 & -0.11 & 0.03 & 0.09 & -0.06 & -0.09 \\
\hline & $r_{\text {subs }}$ & -0.74 & 0.00 & -0.01 & -0.03 & -0.33 & -0.01 & 0.03 & -0.48 \\
\hline & $r_{\text {year }}$ & 0.05 & -0.01 & 0.00 & 0.00 & -0.03 & -0.04 & 0.00 & 0.02 \\
\hline
\end{tabular}


Table 6 (continued)

\begin{tabular}{|c|c|c|c|c|c|c|c|c|c|}
\hline & & Greece & Spain & Italy & France & Germany & Benelux & UK & Scandin. \\
\hline \multicolumn{2}{|l|}{$\varepsilon_{y 1, x \text { othar }}$} & 0.07 & 0.01 & 0.04 & 0.01 & -0.04 & 0.02 & 0.01 & 0.02 \\
\hline \multicolumn{2}{|l|}{$\alpha_{x \text { othact }}$} & -0.45 & 0.05 & 0.01 & -0.39 & -0.02 & -0.27 & -0.17 & 0.18 \\
\hline \multirow[t]{3}{*}{$C_{x \text { othact }, m}$} & $y_{\text {mai }}$ & 0.00 & 0.02 & -0.02 & 0.04 & 0.04 & 0.03 & & \\
\hline & $y_{\text {othar }}$ & -0.18 & -0.01 & -0.12 & 0.00 & 0.01 & -0.03 & 0.00 & 0.00 \\
\hline & $y_{\text {othact }}$ & 0.03 & 0.00 & 0.00 & 0.00 & -0.01 & 0.04 & 0.06 & 0.01 \\
\hline \multirow[t]{8}{*}{$C_{x \text { othact }, k}$} & $x_{\text {fert }}$ & -0.15 & -0.03 & 0.05 & 0.69 & 0.04 & 0.06 & 0.63 & 0.14 \\
\hline & $x_{\text {prot }}$ & 0.88 & 0.03 & 0.07 & -0.14 & 0.01 & 0.03 & -0.10 & -0.33 \\
\hline & $x_{\text {size }}$ & -0.06 & -0.04 & 0.13 & -0.17 & -0.14 & -0.01 & 0.01 & 0.36 \\
\hline & $x_{\text {irr }}$ & -0.13 & 0.00 & 0.00 & 0.00 & -0.01 & 0.01 & -0.02 & -0.01 \\
\hline & $x_{\text {cer }}$ & -0.34 & -0.03 & -0.17 & -0.22 & 0.02 & -0.03 & 0.12 & 0.22 \\
\hline & $x_{\text {mai }}$ & 0.02 & 0.00 & -0.02 & 0.08 & 0.01 & 0.00 & & \\
\hline & $x_{\text {othar }}$ & 0.21 & 0.01 & 0.00 & -0.02 & 0.00 & -0.02 & 0.02 & 0.02 \\
\hline & $x_{\text {othact }}$ & 0.02 & 0.00 & 0.01 & -0.09 & 0.02 & -0.06 & -0.08 & -0.05 \\
\hline \multirow[t]{4}{*}{$C_{x \text { othact }_{2} f}$} & $r_{\text {tmean }}$ & -0.08 & -0.02 & 0.01 & 0.17 & 0.05 & 0.13 & -0.14 & -0.02 \\
\hline & $r_{\text {pmean }}$ & 0.22 & 0.00 & 0.02 & -0.05 & 0.00 & 0.06 & -0.01 & -0.06 \\
\hline & $r_{\text {subs }}$ & -0.03 & 0.00 & 0.00 & 0.03 & -0.09 & 0.00 & -0.46 & -0.44 \\
\hline & $r_{\text {year }}$ & 0.03 & 0.01 & 0.01 & -0.02 & -0.02 & -0.01 & 0.03 & -0.02 \\
\hline \multicolumn{2}{|l|}{$\varepsilon_{y 1, x \text { othact }}$} & -0.01 & -0.01 & 0.01 & -0.09 & -0.08 & -0.06 & -0.10 & -0.01 \\
\hline
\end{tabular}

Parameters in bold are significant with $p<0.05$, in italic with $p<0.10$.

in Spain and France and less in Italy. Nevertheless, land use changes are generally more impacted by other drivers than climatic conditions. Especially in Mediterranean regions there is a significant change in time in the contribution of land uses. Over time, the marginal product of $x_{\text {othact }}$ increases and of $x_{\text {mai }}$ decreases, but the value of $C_{x \text { mai, } r \text { year }}$ is small compared to the other terms adding up to $\varepsilon_{y 1, \text { rmai }}$. In Greece, the positive impact of subsidies $x_{\text {subs }}$ on $\varepsilon_{y 1, x \text { mai }}$ is much larger. Also for other land uses in other regions $x_{\text {subs }}$ has an impact. The output share from $x_{\text {othar }}$ and $x_{\text {othact }}$ generally decreases with more subsidies.

The different land uses are not always complementary among each other, but in several cases the interaction terms with other land uses are positive. In France for example, $x_{\text {cer }}$, $x_{\text {mai }}$ and $x_{\text {othar }}$ are positively related, implying that an increase in one land use increases the contribution of the other land use to total output. Some diversification would thus positively influence total production. In Greece, an increase in $x_{\text {cer }}$ reduces $\varepsilon_{y 1, x \text { mai }}$ and $\varepsilon_{y 1, x o t h a c t}$; only $x_{\text {othar }}$ and $x_{\text {othact }}$ are complementary here.

With few exceptions, $x_{\text {size }}$ negatively influences the elasticity of land uses, especially $\varepsilon_{y 1}$, $x$ cer. On larger farms it is thus less beneficial to increase $x_{\text {cer }}$. Higher $x_{\text {fert }}$ generally increases the marginal product of cereals. A higher $x_{\text {irr }}$ also contributes positively to $\varepsilon_{y 1, x c e r}$ in Greece and France, but negatively to elasticity of other land uses. Also in other regions there is a small impact of $x_{\text {irr }}$, but varying per land use.

\subsection{Returns to scale}

In "Section 2.3.3" we mentioned that a $\Sigma \varepsilon_{y 1, k}>1$ implies increasing returns to scale; more inputs generate a more than proportionate increase in output. Summing up all input elasticities from Tables 5 and 6 gives values slightly larger than 1 for most of the regions. The scale economy measure is highest for Spain (1.27), then Benelux (1.16), Italy (1.05), Greece (1.05), France (1.04), Germany (1.03), Scandinavia (1.01) and lowest in the UK (0.98). 
In Spain and Greece $\varepsilon_{y 1, x m a i}$ contributes mostly to the scale effect, in other regions $\varepsilon_{y 1 x c e r}$ Also $\varepsilon_{y 1, x \text { size }}$ has a high contribution, especially in the UK. This also implies that substitutability between these and other inputs is difficult. When $\varepsilon_{y 1, k}>\varepsilon_{y 1, l}$ a switch means decreasing returns to inputs and thus difficulty in $x_{k}$ to $x_{l}$ substitution. The effect of external factors on inputs can be measured by summing up the $C_{k f}$. The effect of $r_{\text {tmean }}$ on $\Sigma \varepsilon_{y 1, k}$ is highly positive for Spain (0.52), slightly positive for UK, Benelux and Greece and negative for Scandinavia, France and Germany and very negative for Italy $(-0.66)$. The effect of $r_{\text {pmean }}$ is generally small, but $>0.20$ for Benelux, UK and Scandinavia. Subsidies have substantial impact in France (0.30), the UK ( -0.25$)$ and Scandinavia (-1.94). Technological development, markets or other changes did not have a substantial impact on scale economies $(<0.10)$.

\section{Discussion}

\subsection{Methodological discussion}

For the assessment of climate impacts on agriculture new methodologies are needed. Existing methodologies have proved their value, but interactions between climate impacts, other drivers and management are still not well understood. Crop models have been used to project in which regions potential impacts on crop yields are highest (Gitay et al. 2001; Easterling et al. 2007). These models however serve well at the field level, but validation for regional applications of these models remains unsatisfactory as important other factors and relationships are not considered (Tubiello and Ewert 2002). Economists have mainly applied the Ricardian approach (Mendelsohn et al. 1994), and showed that climatic impacts are smaller than crop models would suggest (Mendelsohn and Dinar 1999). An important question, 'how does adaptation influence climate impacts?' cannot be answered however. It is obvious that farmers adapted to changes in the past and will do so in the future. As farmers continuously adapt to prevailing conditions (successfully or not), distinguishing between 'potential impacts', adaptive capacity' and 'residual impacts' (IPCC 2001; Metzger 2005) is practically impossible as 'potential impacts' are not observed and cannot be measured. In every region, on every farm, socio-economic conditions and management influence production and are continuously changing which cannot be ignored.

In this study we use the translog distance function, to empirically assess climate impacts in different regions and the factors that contribute to adaptation to these impacts. This is one of the first studies where interactions between climate and management are explicitly considered. As we are mainly interested in temporal differences, we do not correct for random effects. A random effects model with panel data would change the focus to spatial differences. We select several regions and compare the responses. Applying several models instead of one makes a generalization of the results difficult. It however gives insight in the diversity of responses among regions and farm types. The large differences among regions suggest that models should focus more on smaller and homogenous regions instead of averaging data and results for large and heterogeneous regions. This stresses the need for adequate typologies to perform impact assessments for larger areas.

We use data from farm types instead of individual farms in the model specification. One farm type comprises at least 15 farms. Although individual data would provide more detail, using this data is not possible for privacy reasons. Using grouped data instead of individual farm data in frontier analysis is not uncommon (e.g. Heshmati and Kumbhakar 1997). The 
FADN data of the EU are the only source of micro-economic data that is harmonized, i.e. the bookkeeping principles are the same in all countries (http://ec.europa.eu/agriculture/rica/ index_en.cfm). Although the source is considered reliable, it is possible that unreliable data points have some influence on the results.

Although daily and monthly data on precipitation and temperature are available, it was decided to use the average precipitation and temperature for the January-June period. This was done to avoid confounding of climate variables, although relationships between climate and management are generally more complex. Using average climatic data provides some insights into the impacts of changing climatic conditions. It should be noted that also projections of climate change impacts are generally based on average changes. Although the growing season varies per crop and per region, changing the period for which the data is averaged has small impacts on the results.

\subsection{Actual impacts and adaptive capacity}

Crop model studies generally project more severe climate change impacts on crop yields in southern Europe compared to northern Europe (Olesen and Bindi 2002). In Reidsma et al. (2007) we suggested that farms with higher yields would have a higher capacity to adapt to changing conditions, as they were able to adapt to prevailing conditions. In general, farms with higher intensity, farm size and more arable land obtain higher crop yields. But, in regions where crop yields are higher, income per hectare is not necessarily higher. Also, a temporal analysis showed that although crop yields are generally lower in warmer regions, increases in temperatures do not have more severe effects on crop yields in these regions (Reidsma 2007; Reidsma and Ewert 2008). These results indicate that determining the adaptive capacity of European agriculture is not straightforward.

There is no single measure for the adaptive capacity of European agriculture, as vulnerability and adaptive capacity depend on the temporal reference, sphere (internal/ external/cross-scale), knowledge domain (socio-economic/biophysical/integrated), vulnerable system, attribute of concern and the hazard considered (Füssel 2007). Adaptation to long-term climatic conditions (Reidsma et al. 2007) can therefore differ from adaptation to short-term temporal climate change and variability (Reidsma 2007; Reidsma and Ewert 2008). In the current study we compare eight regions, for which the mentioned six dimensions are the same. We assess cross-scale integrated vulnerability and adaptation of agricultural production of (arable) farmers to climate variability and subsidies from 1990-2003 in these eight EU regions. Hence, their vulnerability and adaptive capacity can be compared.

It is clear that vulnerability and adaptive capacity also differ largely among regions and farm types when the six dimensions are the same. Greece seems to have largely adapted to prevailing conditions, while France is highly impacted by high temperatures. It is observed that increasing certain inputs or land uses can be considered as adaptation strategies to climatic variability, but that this will have little impact on total outputs. Output maximization and risk minimization are often conflicting objectives (e.g. Just 2003; Sinebo 2005). A low technical efficiency is often explained as being related to risk aversion, as risk aversion likely causes greater departure from profit maximization (Just 2003). As technical efficiency is lower in regions with a more variable climate, risk aversion seems to play a larger role in these regions. Increasing farm size causes decreasing risk aversion (Just 2003). Results indicate that this decreasing risk aversion also results in a higher vulnerability to climate variability. In all regions, increasing farm size $\left(x_{\text {size }}\right)$ increases the marginal product. Also, returns to scale are found for almost all regions. But, when we look 
at regions where average $x_{\text {size }}$ is large (e.g. France, UK, Benelux), $x_{\text {size }}$ amplifies the negative impact of higher temperatures $\left(r_{\text {tmean }}\right)$.

It is clear that indicators of regional-level adaptive capacity (Schröter et al. 2003; Brooks et al. 2005; Haddad 2005) do not suffice to estimate which factors reduce vulnerability of European farmers. Adaptation and vulnerability of European farmers depend on (1) the output they produce, (2) farm characteristics, such as the type of land use, type of crop, intensity, farm size and interactions between these factors and (3) regional conditions, such as long-term climatic conditions and socio-economic conditions. However, these factors strongly interact resulting in different responses among regions.

\subsection{Adaptation strategies and implications for modelling}

There are many different types of adaptation strategies to reduce impacts of climate change (Smit and Skinner 2002), for which profitability and hence adoption rate is different in different situations. Several of these strategies have been assessed in this study. Adaptation strategies that can decrease the yield gap (i.e. the difference between potential and actual yield) are e.g. adjustment of fertilizer use, pest and weed control and irrigation management. At higher temperatures $\left(r_{\text {tmean }}\right)$ the contribution of fertilizers $\left(x_{\text {fert }}\right)$ increases in Italy, France and the UK, implying that intensive farmers adapt better, while it decreases in Scandinavia. The projections for northern Europe are that with higher potential yields at higher temperatures, more fertilizers will be used (Olesen and Bindi 2002). This might have negative impacts on the environment. Our results show that the marginal product of fertilizers actually decreases, suggesting that until now this was not an efficient adaptation strategy to adapt to higher temperatures. A higher crop protection has both positive and negative impacts, while increasing irrigated area only has a positive impact in Greece.

Economic adaptation to climate change also involves the choice of crop species and other agricultural activities. Models considering climate-land use interactions, generally relate land use changes to changes in potential productivity (e.g. IMAGE team 2001; Eickhout et al. 2007). The frontier analysis in this study indicates that land use changes are influenced by climatic conditions (again, differently in different regions), but that subsidies and the general trend (e.g. technology and markets) have a larger impact. Considering these factors influencing climate-land use interactions and relating projections to actual instead of potential productivity will improve reliability of future projections of land use changes (see also Ewert et al. 2005; Rounsevell et al. 2005; Rounsevell et al. 2006; Ewert et al. 2007).

The increasing returns to scale suggest that increasing inputs would be beneficial in all regions. One key aspect of economic performance and viability not considered in this study however, is off-farm income. Especially for small farms this is important, and allowing for this component of farm 'output' suggests less scale economies and a higher technical efficiency (Morrison Paul and Nehring 2005). As the FADN database does not provide data on off-farm income, we could not analyse the impact of this. The larger the farm, the less labour is available for off-farm activities. Therefore, smaller farms may be better able to cope with output variability. Reilly (2002) suggested that medium scale farms were most vulnerable, as there is little labour available for off-farm activities, and also little capital to adapt to changing conditions. This study indicates that adaptation strategies differ per farm type, but as regional conditions differ largely, the efficiency of adaptation strategies also varies and is not always consistent with theoretical assumptions.

Our results clearly show the complexity of interactions between climatic, farm management and other factors on agriculture. We were not able to identify consistent 
response patterns to climate change across regions and farm types that could be used in either crop models or economic models to improve future projections of climate change impacts. Instead, it becomes evident that models used for climate change impact assessment need to account for both bio-physical and economic processes including interactions among these. Recently, efforts have been made to combine crop and farm models (Kokic et al. 2007; van Ittersum et al. 2008) and even link these to market models (van Ittersum et al. 2008). Such model compositions should improve projections of climate change impacts on agriculture but need further evaluation.

\section{Conclusion}

In this study we use the translog distance function, to empirically assess (1) impacts of climate and subsidies on agricultural production in different regions and (2) interactions with inputs and other factors which contribute to adaptation to these impacts. In the period studied (1990-2003) various changes in both inputs and outputs were observed which can partly be related to climatic variability and change, but also to subsidies and other developments (e.g. markets, technological development). Our results show that impacts differ per region, and that 'actual impacts' cannot be explicitly separated into 'potential impacts' and 'adaptive capacity' as often proposed for vulnerability assessment. Farmers adapt their practices to prevailing conditions and continuously adapt to changing conditions. Therefore, 'potential impacts' will not be observed in practice leaving it as mainly theoretical concept. Factors that contribute to adaptation also differ per region. In some regions more fertilizers or more irrigation can mitigate impacts, while in other regions this amplifies impacts. To project impacts of future climate change on agriculture, current farm management strategies and their influence on current production should be considered This clearly asks for improved integration of biophysical and economic models.

Acknowledgements We thank the Netherlands Environmental Assessment Agency (MNP), Bilthoven, The Netherlands for providing the funding of the Ph.D. project of PR in which this study was performed. We also thank the EU-funded SEAMLESS project (System for Environmental and Agricultural Modelling; Linking European Science and Society, contract no.: 010036-2) for providing the FADN data and funding for FE. Thanks also go to JRC-Agrifish MARS STAT and Hendrik Boogaard for providing the climate data from the MARS project.

Open Access This article is distributed under the terms of the Creative Commons Attribution Noncommercial License which permits any noncommercial use, distribution, and reproduction in any medium, provided the original author(s) and source are credited.

\section{References}

Andersen E, Verhoog AD, Elbersen BS, Godeschalk FE, Koole B (2006) A multidimensional farming system typology. SEAMLESS Report No.12, SEAMLESS integrated project, EU 6th Framework Programme. http://www.seamless-ip.org/Reports/Report_12_PD4.4.2.pdf

Andersen E, Elbersen B, Godeschalk F, Verhoog D (2007) Farm management indicators and farm typologies as a basis for assessments in a changing policy environment. J Environ Manage 82:353-362 doi:10.1016/j.jenvman.2006.04.021

Brooks N, Adger WN, Kelly PM (2005) The determinants of vulnerability and adaptive capacity at the national level and the implications for adaptation. Glob Environ Change 15:151-163 doi:10.1016/j. gloenvcha.2004.12.006 
Coelli TJ, Perelman S (1996) Efficiency measurement, multi-output technologies and distance functions: with application to European railways. CREPP Working Paper 96/05. University of Liege

Coelli T, Perelman S (2000) Technical efficiency of European railways: a distance function approach. Appl Econ 32:1967-1976 doi:10.1080/00036840050155896

Darwin RR (1999) The impact of global warming on agriculture: a Ricardian analysis. Am Econ Rev 89:1049-1052 Comment

Easterling WE, Aggarwal PK, Batima P, Brander KM, Erda L, Howden SM et al (2007) Food, fibre and forest products. In: Parry ML, Canziani OF, Palutikof JPvd, Linden PJ, Hanson CE (eds) Climate change 2007: impacts, adaptation and vulnerability. Contribution of Working Group II to the Fourth Assessment Report of the Intergovernmental Panel on Climate Change. Cambridge University Press, Cambridge, pp 273-313

Eickhout B, van Meijl H, Tabeau A, van Rheenen T (2007) Economic and ecological consequences of four European land use scenarios. Land use policy 24:562-575 doi:10.1016/j.landusepol.2006.01.004

Ewert F, Rounsevell MDA, Reginster I, Metzger MJ, Leemans R (2005) Future scenarios of European agricultural land use. I: estimating changes in crop productivity. Agric Ecosyst Environ 107:101-116 doi:10.1016/j.agee.2004.12.003

Ewert F, Porter JR, Rounsevell MDA (2007) Crop models, CO2, and climate change. Science 315:459-460 doi:10.1126/science.315.5811.459c

Färe RS (1988) Fundamentals of production theory. Springer, Berlin

Färe RS, Grosskopf S, Lovell CAK (1994) Production frontiers. Cambridge University Press, Cambridge

Farrell MJ (1957) The measurement of productive efficiency. J R Stat Soc ACXX:253-290

Füssel H-M (2007) Vulnerability: a generally applicable conceptual framework for climate change research. Glob Environ Change 17:155-167 doi:10.1016/j.gloenvcha.2006.05.002

Gitay H, Brown SD, Easterling W, Jallow B (2001) Ecosystems and their goods and services. In: McCarthy JJ, Canziani OF, Leary NA, Dokken DJ, White KS (eds) Climate change 2001. Impacts, adaptation, and vulnerability. Cambridge University Press, Cambridge, pp 237-315

Greene WH (1995) LIMDEP version 7.0 user's manual. Econometric Software Inc., Bellport

Haddad BM (2005) Ranking the adaptive capacity of nations to climate change when socio-political goals are explicit. Glob Environ Change 15:165-176 doi:10.1016/j.gloenvcha.2004.10.002

Heshmati A, Kumbhakar SC (1997) Estimation of technical efficiency in Swedish crop farms: a pseudo panel data approach. J Agric Econ 48:22-37

IMAGE team (2001) The IMAGE 2.2 implementation of the SRES scenarios: a comprehensive analysis of emissions, climate change and impacts in the 21 st century. National Institute of Public Health and the Environment, Bilthoven

IPCC (2001) Climate Change 2001. Impacts, adaptation and vulnerability. Cambridge University Press, Cambridge

Just RE (2003) Risk research in agricultural economics: opportunities and challenges for the next twenty-five years. Agr Syst 75:123-159

Kokic P, Nelson R, Meinke H, Potgieter A, Carter J (2007) From rainfall to farm incomes - transforming advice for Australian drought policy. I. Development and testing of a bioeconomic modelling system. Aust J Agric Res 58:993-1003

Mendelsohn R, Dinar A (1999) Climate change, agriculture and developing countries: does adaptation matter? World Bank Res Obs 14:277-293

Mendelsohn R, Nordhaus WD, Shaw D (1994) The impact of global warming on agriculture - a Ricardian analysis. Am Econ Rev 84:753-771

Mengel K (1983) Responses of various crop species and cultivars to fertilizer application. Plant Soil 72 : 305-319

Metzger MJ (2005) European vulnerability to global change. A spatially explicit and quantitative assessment. $\mathrm{Ph} . \mathrm{D}$. thesis. Wageningen University, Wageningen, pp 192

Metzger MJ, Rounsevell MDA, Acosta-Michlik L, Leemans R, Schroter D (2006) The vulnerability of ecosystem services to land use change. Agric Ecosyst Environ 114:69-85

Morrison Paul CJ, Nehring R (2005) Product diversification, production systems, and economic performance in U.S. agricultural production. J Econom 126:525-548

Morrison Paul CJ, Johnston WE, Frengley GAG (2000) Efficiency in New Zealand sheep and beef farming: the impacts of regulatory reform. Rev Econ Stat 82:325-337

Nakícenovíc N, Alcamo J, Davis G, de Vries B, Fenhann J, Gaffin S, Gregory K, Grübler A, Jung TY, Kram T, Emilio la Rovere E, Michaelis L, Mori S, Morita T, Pepper W, Pitcher H, Price L, Riahi K, Roehrl A, Rogner H-H, Sankovski A, Schlesinger ME, Shukla PR, Smith S, Swart RJ, van Rooyen S, Victor N, Dadi Z (2000) Special report on emissions scenarios. Cambridge University Press, Cambridge 
O’Brien KL, Leichenko RM (2000) Double exposure: assessing the impacts of climate change within the context of economic globalization. Global Environ Change 10:221-232

Olesen JE, Bindi M (2002) Consequences of climate change for European agricultural productivity, land use and policy. Eur J Agron 16:239-262

Reidsma P (2007) Adaptation to climate change: European agriculture. Ph.D. thesis. Wageningen University, Wageningen, pp 216

Reidsma P, Ewert F (2008) Regional farm diversity can reduce vulnerability of food production to climate change. Ecology and Society (in press)

Reidsma P, Ewert F, Oude Lansink A (2007) Analysis of farm performance in Europe under different climate and management conditions to improve understanding of adaptive capacity. Clim Change 84:403-422

Reilly (2002) Agriculture: the potential consequences of climate variability and change for the United States. University Press, Cambridge

Rounsevell MDA, Ewert F, Reginster I, Leemans R, Carter TR (2005) Future scenarios of European agricultural land use II. Projecting changes in cropland and grassland. Agric Ecosyst Environ 107: $117-135$

Rounsevell MDA, Reginster I, Araujo MB, Carter TR, Dendoncker N, Ewert F, House JI, Kankaanpaa S, Leemans R, Metzger MJ (2006) A coherent set of future land use change scenarios for Europe. Agric Ecosyst Environ 114:57-68

Schlenker W, Hanemann WM, Fisher AC (2005) Will U.S. agriculture really benefit from global warming? Accounting for irrigation in the hedonic approach. Am Econ Rev 95:395-406

Schröter D, Acosta-Michlik L, Reidsma P, Metzger M, Klein RJT (2003) Modelling the vulnerability of ecosocial systems to global change: human adaptive capacity to changes in ecosystem service provision. Paper presented at the Fifth Open meeting on the Human Dimensions of Global Change, Montreal, 1618 October, 2003

Schröter D, Cramer W, Leemans R, Prentice IC, Araújo MB, Arnell NW, Bondeau A, Bugmann H, Carter TR, Gracia CA, Vega-Leinert ACdl, Erhard M, Ewert F, Glendining M, House JI, Kankaanpää S, Klein RJT, Lavorel S, Lindner M, Metzger MJ, Meyer J, Mitchell TD, Reginster I, Rounsevell M, Sabaté S, Sitch S, Smith B, Smith J, Smith P, Sykes MT, Thonicke K, Thuiller W, Tuck G, Zaehle S, Zierl B (2005) Ecosystem service supply and vulnerability to global change in Europe. Science 310:1333-1337

Sinebo W (2005) Trade off between yield increase and yield stability in three decades of barley breeding in a tropical highland environment. Field Crops Res 92:35-52

Smit B, Skinner M (2002) Adaptation options in agriculture to climate change: a typology. Mitig Adapt Strategies Glob Chang 7:85-114

Tubiello FN, Ewert F (2002) Simulating the effects of elevated CO2 on crops: approaches and applications for climate change. Eur J Agron 18:57-74

van Ittersum MK, Ewert F, Heckelei T, Wery J, Alkan Olsson J, Andersen E, Bezlepkina I, Brouwer F, Donatelli M, Flichman G, Olsson L, Rizzoli AE, van der Wal T, Wien JE, Wolf J (2008) Integrated assessment of agricultural systems - a component-based framework for the European Union (SEAMLESS). Agric Syst 96:150-165

van Meijl H, van Rheenen T, Tabeau A, Eickhout B (2006) The impact of different policy environments on agricultural land use in Europe. Agric Ecosyst Environ 114:21-38

Westhoek H, van den Berg M, Bakker J (2006) Scenario development to explore the future of Europe's rural areas. Agric Ecosyst Environ 114:7-20 